Illinois State University

ISU ReD: Research and eData

Theses and Dissertations

$4-1-2021$

\title{
Improving Failure Mode \& Effect Analysis (Fmea) Method Using Discrete Event Simulation
}

Adil Abdukeyum

Illinois State University, adil.abdukeyum@gmail.com

Follow this and additional works at: https://ir.library.illinoisstate.edu/etd

Part of the Statistics and Probability Commons

\section{Recommended Citation}

Abdukeyum, Adil, "Improving Failure Mode \& Effect Analysis (Fmea) Method Using Discrete Event Simulation" (2021). Theses and Dissertations. 1348.

https://ir.library.illinoisstate.edu/etd/1348

This Thesis is brought to you for free and open access by ISU ReD: Research and eData. It has been accepted for inclusion in Theses and Dissertations by an authorized administrator of ISU ReD: Research and eData. For more information, please contact ISUReD@ilstu.edu. 
IMPROVING FAILURE MODE AND EFFECT ANALYSIS (FMEA) METHOD USING DISCRETE

EVENT SIMULATION

\begin{abstract}
ADILIJIANG ABUDUKEYIMU
40 Pages

To improve system performances and process dependability, analyzing the system accurately is an essential step but difficult to achieve and it is even more challenging if the system is complex and dynamic. A popular tool called FMEA has been widely used to analyze and improve systems. However, both academia and industry acknowledge its subjectivity and lack of cause-effect analysis capability. Therefore, in this research, the author presents a more objective and data-driven method called Discrete Event Simulation to improve FMEA's analysis capability. Also, a step-by-step analysis approach is presented by a case study to showcase how the Discrete Event Simulation may enhance FMEA. The case study illustrates that Discrete Event Simulation can quantify FMEA's rating process for Severity, Occurrence, and Detection of a failure mode so it could conduct a more reliable evaluation on system performance.
\end{abstract}

KEYWORDS: Discrete Event Simulation, Failure Mode \& Effect Analysis, FMEA, Cause-effect Analysis, Performance Improvement, Dependability Analysis 
IMPROVING FAILURE MODE AND EFFECT ANALYSIS (FMEA) METHOD USING DISCRETE

EVENT SIMULATION

ADILIJIANG ABUDUKEYIMU

A Thesis Submitted in Partial

Fulfillment of the Requirements for the Degree of

MASTER OF SCIENCE

Department of Technology

ILLINOIS STATE UNIVERSITY

2021 
Copyright 2021 Adilijiang Abudukeyimu 
IMPROVING FAILURE MODE AND EFFECT ANALYSIS (FMEA) METHOD USING DISCRETE

EVENT SIMULATION

ADILIJIANG ABUDUKEYIMU

COMMITTEE MEMBERS:

Borinara Park, Chair

Jaby Mohammed

Klaus Schmidt 


\section{CONTENTS}

CONTENTS

TABLES

FIGURES

CHAPTER I: INTRODUCTION

CHAPTER II: LITERATURE REVIEW 3

CHAPTER III: PROBLEM STATEMENT 9

CHAPTER IV: RESEARCH METHODOLOGY 10

CHAPTER V: CASE STUDY 11

$\begin{array}{ll}\text { Warehouse Operation } & 11\end{array}$

$\begin{array}{ll}\text { Simulation Description } & 13\end{array}$

FMEA On Distribution Center: Phase A 15

Discrete Event Simulation on Distribution Center: Phase B 20

$\begin{array}{ll}\text { Level 1- One KPI } & 20\end{array}$

Level 2- Two KPIs $\quad 22$

Level 3- Three KPIs $\quad 25$

Summary on Discrete Event Simulation $\quad 28$

$\begin{array}{ll}\text { CHAPTER VI: CONCLUSION } & 30\end{array}$

CHAPTER VII: FUTURE STUDIES

$\begin{array}{ll}\text { REFERENCES } & 34\end{array}$

APPENDIX (COMPLETE FMEA ANALYSIS) 


\section{TABLES}

Table

Page

1. Main Phases and Related Critical Resources, and Process Details

2. Ratings for The Severity of a Failure (Andrejić and Kilibarda, 2017)

3. Ratings for The Occurrence of a Failure (Andrejić and Kilibarda, 2017)

4. Ratings for The Detection (Andrejić and Kilibarda, 2017)

5. Example of Analysis A

6. FMEA Based Comparison Analysis (FMEA's Inability to Conduct "What If" Scenarios)

7. 1st Phase of Step by Step Analysis Development to Improve FMEA Via Simulation (Illustration Using Forklift Amount in Warehouse Operation)

8. 2nd Phase of Step by Step Analysis Development to Improve FMEA Via Simulation (Illustration Using Forklift Amount in Warehouse Operation)

9. 3rd Phase of Step by Step Analysis Development to Improve FMEA Via Simulation (Illustration using Forklift Amount in Warehouse Operation)

10. Generalized Step by Step Analysis Approach 


\section{FIGURES}

Figure

1. An operational scene of the distribution center used in the case

2. Layout of the center

3. Details of the simulation logic of the distribution center

4. Parameters in the simulation

5. Forklifts utilization- Analysis B (20 forklifts)

6. Forklifts utilization- Analysis B`(30 forklifts)

7. Analysis C- forklifts utilization \& order assembling mean waiting time (20 forklifts)

8. Analysis $\mathrm{C}^{\prime}$ - forklifts utilization $\&$ order assembling mean waiting time (30 forklifts)

9. Analysis D- forklifts utilization \& order assembling mean waiting time \& free main storage space (20 forklifts)

10. Analysis D’- forklifts utilization \& order assembling mean waiting time \& free main storage space (30 forklifts)

11. RPN stabilized point using KPI (20 forklifts)

12. RPN stabilized point using KPI (30 forklifts)

13. Generalized RPN stabilized Point 


\section{CHAPTER I: INTRODUCTION}

Continuous improvement of products and processes plays a significant role for companies to have competitive advantages in highly challenging markets such as manufacturing, service sector, and healthcare (Doshi \& Desai, 2017). Hence, organizations need effective approaches to achieve sustainable and ongoing performance improvement effort to achieve such a goal. One such methodology, Lean Six Sigma, is a comprehensive practice to eliminate the defects and wastes in a system with various improvement tools to address the system related issues.

Among these tools, FMEA (Failure Modes \& Effect Analysis) is widely adopted by industries, which is a systematic method designed for dependability analysis (Scipioni et al., 2002). It is used to recognize possible failures and their impacts on processes and products (Doshi \& Desai, 2017). FMEA was introduced for the first time in 1949 by the US army. During the 1970s, due to its powerful and valid features, its implementation also spreaded into aerospace, automotive, and general manufacturing (Scipioni et al., 2002).

FMEA is a team activity that involves, first, studying and evaluating the processes or products (Scipioni et al., 2002); then, listing the possible failures and their effects; and, lastly, establishing future actions that could eliminate or reduce potential failures (Hekmatpanah et al., 2011). To determine the level of potential risks related to the failure of a certain element of the process, the risk priority number (RPN) is calculated by multiplying its occurrence, severity, and detection of a failure. Each element is ranked based on a 1 to 10 scale using its RPN value, and higher the RPN is, the more urgency of the future actions is required (Hekmatpanah et al., 2011).

FMEA is an effective tool to improve processes by proactively identifying and preventing high risk elements in the system. The case study done by Hekmatpanah et al. (2011) shows that after implementing FMEA, the net profit of the organization in the study increased significantly. Another study 
indicates that when FMEA is integrated with HACCP (Hazard Analysis Critical Control Points) system in a food company, it greatly improved the process reliability of the system in the company (Scipioni et al., 2002). 


\section{CHAPTER II: LITERATURE REVIEW}

FMEA is a well-known Six Sigma tool that has been widely applied by various industries. However, FMEA's deficiencies are also acknowledged by both academia and industry (Spreafico et al., 2017). Therefore, many researches have been done to improve FMEA's analysis capability so it can be more efficient and accurate.

For instance, Sutrisno et al. (2016) realized that FMEA over relies on RPN and ignore the business environment that an organization is within. This may result in inaccurate measurement of economic, managemental, operational impact of a failure mode. Therefore, Sutrisno et al. (2016) introduced integrating SWOT (strength, weakness, opportunity and threat analysis) analysis into FMEA in order to select most suitable future actions by analyzing internal and external factors that the organizations face. After listing the failure modes using FMEA, they first recognized the SWOT variables. They were the strength and weakness variables that an organization has internally, and opportunity and threat variable could be faced by implementing a specific future action. After this, future actions' preference scores and benefit indexes were calculated using SWOT formula. The third main step was to combine BCOR2 approach with SWOT analysis to get the final preferred action. BCOR2 represents a specific action's benefit, implementation cost, weight of impact, and organizational resilience to that action. The higher the final preferred score, the more suitable the action is for the organization. In addition, the research used a case study of a gas producing company to illustrate SWOT analysis's efficiency and usefulness. After integrating SWOT analysis into FMEA analysis, not the action with higher RPN but the more suitable future actions were chosen to be implemented after thorough evaluation of business environment. SWOT analysis covered the elements that FMEA does not, such as, benefit, cost, opportunity, risk, organizational readiness. This may result in helping decision makers make better decision without overlooking the impact of the business environment. Hence, SWOT analysis approach 
could be an effective tool to improve FMEA's future action selection (Sutrisno et al., 2016). However, one factor in the research should be pointed out that even though SWOT analysis is an effective tool, there were some subjective knowledge involved in rating process in SWOT approach. For example, the process of calculating an action's benefit needs rating the impact of that action based on what the FMEA cross-functional team thinks. This may affect the whole result (Sutrisno et al., 2016).

Another research introduced combination of FTA and FMEA to improve failure analysis. Peeters et al. (2018) mentioned the FMEA's disadvantages as well. First, FMEA could be very time consuming if it is applied thoroughly. Secondly, FMEA is challenging when it is applied for a new and complex system, because FMEA requires team members to have knowledge and experience on the system. Third, through FMEA, it is difficult to achieve enough depth of analysis to fully understand the relationship between the system and failure behaviors. Therefore, they suggested that combination of FTA and FMEA might help improve the overall performance of failure analysis. FTA represents Fault Tree Analysis. It is an approach that analyzes the system from top to down. That means, unlike FMEA, FTA is a structured approach that considers system level, function level, and component level in a system. FTA is a logic diagram uses logic gates, such as, "OR", “AND”, and inhibit or conditional gates to represent the relationships between system failures and cause of failures. With that, the method the authors used was to apply FTA, first, to identify possible failures level by level described above. Then, they applied FMEA to analyze the criticality of the failures in each level. In other word, based on RPN, critical failures and, in the end, future actions were decided. The contributions of this type approach were, first, it provided more detailed failure analysis since different levels of the system were analyzed thoroughly. Secondly, this approach provided efficiency for analyzing a system. Because FTA analyzes the system from top to down, in a structured manner and this can offer better understanding of a system. They also conducted a case study in an additive manufacturing company for metal printing to present the idea. The company was satisfied with the result. They could use the result to understand their additive 
manufacturing system profoundly and redesign it. Also, they could design an effective maintenance program to reduce some critical failures' risks. All things considered, combination of FTA and FMEA was an effective way to improve efficiency of failure analysis. However, the authors also mentioned that there were some downsides of this type approach as well. For example, this approach may have limited efficiency if it is applied to a more complex system that has multiple sub-systems. In other word, combination of FTA and FMEA can provide more structured analysis on relatively less complex systems (Peeters et al., 2018).

Chang, and Sun (2009) introduced applying DEA to enhance assessment capacity of FMEA. They discuss that the fundamental problem of FMEA is that it solely relies on RPN to quantify the risk of failures without properly taking factors that contribute to risk into consideration. This may result in inaccurate decision in terms of tackling with failures. DEA, as a linear programing-based methodology, tests inputs and outputs to offer efficiency scores among DMUs. DMU stands for Decision Making Unit. Efficiency score of a DMU is the ratio of the sum of weighted inputs and the sum of weighted outputs. DMU is equivalent to failure mode in FMEA. SODs in FMEA are equivalent to multiple inputs in DEA. With that, the higher the efficiency score the higher priority a failure mode has. Chang and Sun (2009) used Dillibabu and Krishnaiah's (2006) study to illustrate the DEA's efficiency. Dillibabu and Krishnaiah (2006) applied FMEA to improve defect-free software in their study. After applying DEA to the same failure modes, they figured the new result was different. The priorities of those failure modes were different than previous study. That means, DEA could provide different perspective for decision makers. Because simply relying on RPN does not tell them the whole story. Therefore, DEA, as a quantitative tool, can be helpful for management to allocate their resources more efficiently (Chang \& Sun, 2009). Nevertheless, DEA has its disadvantages as well. First, DEA's results are sensitive to the selection of inputs (Berg, 2010, p. 44-45). DEA uses SODs from FMEA to calculate inputs. Usually, SODs are rated 
subjectively based on knowledge and experience. This may affect DEA's result. Secondly, it could be difficult to understand for people who do not have a mathematic background.

Shaker et al. (2019) approach was integrating two-phase quality function deployment (QFD) into FMEA for improving the latter one. After reviewing abundant literatures regarding improving the FMEA, they discussed that FMEA's over-reliance on RPN can cause negligence on interrelationship among various factors such as, failure modes, failure effects, and failure causes. So, they tried to apply QFD- a customer-driven method to understand customers' needs- in an integrative way to improve FMEA. In the first phase, there were two types of outputs. They were prioritized failure effects and prioritized failure modes. The importance rates of the failure effects could be considered as Severity and they were gained by conventional FMEA. Then interrelationship weights between these failure modes and failure effects were rated based on 1: weak; 3: moderate; and 9: strong. After this, the importance rates of the failure modes were multiplied by the interrelationship weights. Finally, the total weight of each failure mode was sum up and entered to the second phase as a new importance rate.

In the second phase, there were also two outputs. They were prioritized failure causes and prioritized failure modes. Other computations were same as in the first phase. The authors used a steelmanufacturing company as a case study to showcase their approach's effectiveness. The contribution of this approach was that it considered the interrelationship between failure modes, failure effects, and failure causes. More importantly, this approach could provide more efficiency for manufacturing departments and maintenance departments in organizations that have continuous production lines (Shaker et al., 2019). However, in this approach, the importance rates were obtained by conventional FMEA on a 1-10 scale. It is difficult to accurately quantify the importance rate. Hence, if importance rate reduces or increases, even by 1 , due to different perspectives from FMEA team, the result could be affected. Also, same problem can apply to interrelationship weights. 
Liu et al. (2015) proposed a hybrid FMEA integrated with VIKOR method, decision making trial and evaluation laboratory (DEMATEL), and analytic hierarchy process (AHP). Regarding FMEA, they mentioned that over-reliance on RPN and the way it is calculated is a disadvantage that many researchers agree with. By contrast, the new approach they suggested considers interrelation between failure modes and failure effects and provides more thorough cause-effect analysis. Therefore, their proposed approach could complete FMEA's downside. The authors new hybrid approach has three phases. They first applied FMEA to identify the failure modes and calculated their RPNs. Then they apply VIKOR method to determine the effects of failure modes. In the second phase, DEMATEL was used to create an influential relation map among failure modes and causes. In the final step, based on DEMATEL's result, AHP was applied to obtain final influential weights and failure modes were prioritized. They also conducted a case study using diesel engine's turbocharger system. After applying the new approach, final rankings of the failure modes were different than the result obtained by conventional FMEA. That means, the authors' approach could provide a more accurate and comprehensive analysis in terms of considering interrelationships between failure modes and failure effects. However, they also mentioned three downsides of the approach. One of them was that conventional FMEA provided the quantification of failure modes' factors such as Severity, Occurrence, and Detection. But in reality, it is difficult to quantify failure modes' factors due to complexity of a system (Liu et al., 2015).

Spreafico et al. (2017) conducted a wide and very thorough state-of-the-art review of FMEA and its improvement from 1978 to 2016. They collected documents from both academia and industry and classified the documents based on authors, source, and four technical classes. The technical classes were applicability, cause and effect, risk analysis, and problem solving of the FMEA. Spreafico et al. (2017) mentioned that the difference of the review was that it extended the analysis to patent fields. Also, they applied Espacenet worldwide service for the patent research, which is considered the most proliferated and complete collection of patent documents. Most critically, they manually classified the documents in 
order to exclude documents describing only applications without suggesting any methodological enhancement and documents with too few quotes compared to the years of publication. With that, they reviewed 220 scientific papers and 109 patents. After reviewing all the selected documents, their findings about FMEA was that, in applicability, subjectivity and time consuming was the biggest problem for both academia and industry; in cause and effect, lack of secondary effects modelling for academia and difficulty to decide the right level of detail for industry was the main problem; in risk analysis, high subjectivity during the risk evaluation was main problem and the critic mainly came from academia; in problem solving, to both academia and industry, lack of well-defined problems with specific goals and lack of clearly-defined, clearly expected solution was the main problem.

As mentioned, they also reviewed the improvement attempted by both academia and industry. Their finding was that many different methods such as, Fuzzy logic, Functional Analysis, TRIZ, Historical data DB, QFD, FTA, and many other methods, have been used to improve FMEA's four technical classes. They discussed such approaches could offer incremental solution for the specific problems. However, they also mentioned some remaining problems FMEA. First, there were no effective solutions for time consuming and boredom of the FMEA. Second, there were no solutions were found to radically change the operation sequence of FMEA or solution for better ranking intervention (Spreafico et al., 2017). 


\section{CHAPTER III: PROBLEM STATEMENT}

Despite numerous researches have been done to improve FMEA, researchers identify some of its fundamental problems, such as subjective analysis and lack of cause-effect analysis capability, are still open to be enhanced (Spreafico et al., 2017; Chang \& Sun, 2009). With that, although FMEA has its quantitative part like RPN, the approach to obtain these numbers are still subjective and qualitative. Practitioners from different domains use heavily their knowledge and past experience in a subjective manner when quantifying the level of risks (Scipioni et al., 2002). Therefore, the RPN can fluctuate quite a bit depending on whose opinions are valued more. This makes the outcomes of the FMEA analysis not reliable and inconsistent because of its methodological bias (Hekmatpanah et al., 2011). Furthermore, FMEA has a limited cause-effect analysis capability because it lacks depth and objectivity in its analysis. This weakness becomes more obvious when FMEA is applied to a new or complex system (Peeters et al., 2018; Shaker et al., 2019; Seyed-Hosseini et al., 2006). Hence, FMEA may not be able to provide valuable information for decision-makers. As a result, subjective analysis and lack of cause-effect analysis capability may make FMEA a practice with less confidence and accuracy, driven more by qualitative analysis even though it has to be objective and quantitative (Murphy et al., 2011). 


\section{CHAPTER IV: RESEARCH METHODOLOGY}

To enhance FMEA's subjectivity and lack of cause-effect analysis capability, in this research, a simulation technique called discrete event simulation (DES) will be introduced as a potential technique to complement FMEA. Discrete event simulation is a computer simulation method that models various

reallife systems. The simulated systems may consist of one or multiple events that occur independently in a discrete time manner. The discrete event simulation is chosen because, unlike FMEA, it relies on evidentiary data to analyze the system behavior and cause-effect of failures with clear solutions. Hence, it has a strong, objective foundation to evaluate each failure's severity, occurrence, detection, and ultimately their RPNs (Jacobson et al., 2006; Parks et al., 2011; Misra, 1986; Raunak et al., 2009; Wohlgemuth et al., 2006; Sumari et al., 2013) which are the elements FMEA's weaknesses are embodied in.

To explain the proposed method, a case study regarding a relatively complex system is conducted by the author in later session. There are two phases in the study. In phase A, conventional FMEA is conducted independently on the system and its weaknesses are discussed. In phase B, integrated method is used. The failure modes obtained from FMEA are utilized first. But discrete event simulation is applied to analyze the system behavior and cause-effect of each failure mode. There will be three steps of analysis in this phase. Each step uses different KPI(s) and two scenarios to analyze the failure mode from different perspectives. More importantly, to showcase how discrete event simulation can enhance FMEA by its quantitative approach, each failure mode's RPN is reevaluated based on the outcome of the simulation and compared with FMEA's result. RPN score will be dynamic from one analysis to another. This may result in different insight for cause-effect of the failure mode because the system is analyzed in more depth and in different environments. With that, discrete event simulation's result may offer new ways of conducting FMEA more efficiently. 


\section{CHAPTER V: CASE STUDY}

In this research, as a way of demonstrating how the dependability analysis capability of FMEA can be enhanced, the discrete event simulation is introduced and directly compared against FMEA. To better illustrate the FMEA can be enhanced by discrete event simulation, a case involving a distribution center (DC) will be used. A visual snapshot of the DC used is shown in Figure 1. The DC simulation model is an existing example model from AnyLogic team. The FMEA regarding DC was conducted by the author independently.

Figure 1. An operational scene of the distribution center used in the case

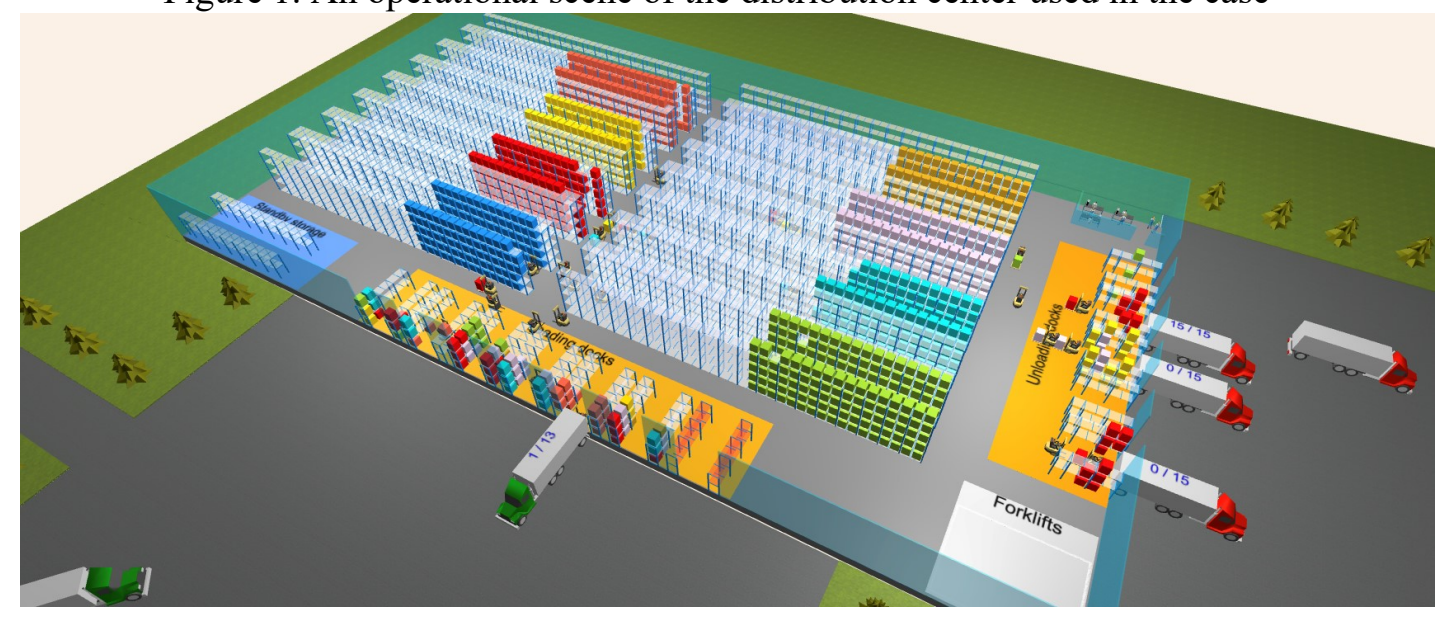

\section{Warehouse Operation}

In this case study, the operation in 24 hours shift distribution center involves three main processes. They are unloading, assembly, and loading. First, in the unloading process, unloading trucks deliver pallets to an available unloading dock. Then, pallets are unloaded from the trucks using forklifts and placed in the receiving dock area. After this, pallets are transported to the main storage racks. Second, in the assembly process, orders from distribution center's clients are assembled from the pallets. An order can be of same or different types of pallets and are assembled by forklifts. In this process, enough space 
for the assembly area near the loading docks is needed (or a backup storage area can be used in case there is not enough space there), and main storage must have the required number of pallets for them to be assembled. Third, in the loading process, once the orders are assembled, a loading truck is assigned to the loading dock to receive the order. Then forklifts will load the orders into the truck from assembly area. The order quantity for a truck must take up at least half of its capacity.

The simulation model has the layout of the distribution center to display the progress of the operation. The layout is presented in Figure 2 where the main storage area, standby storage, loading and unloading docks are presented. These elements help analyzing the processes while the simulation is running.

Figure 2: Layout of the center

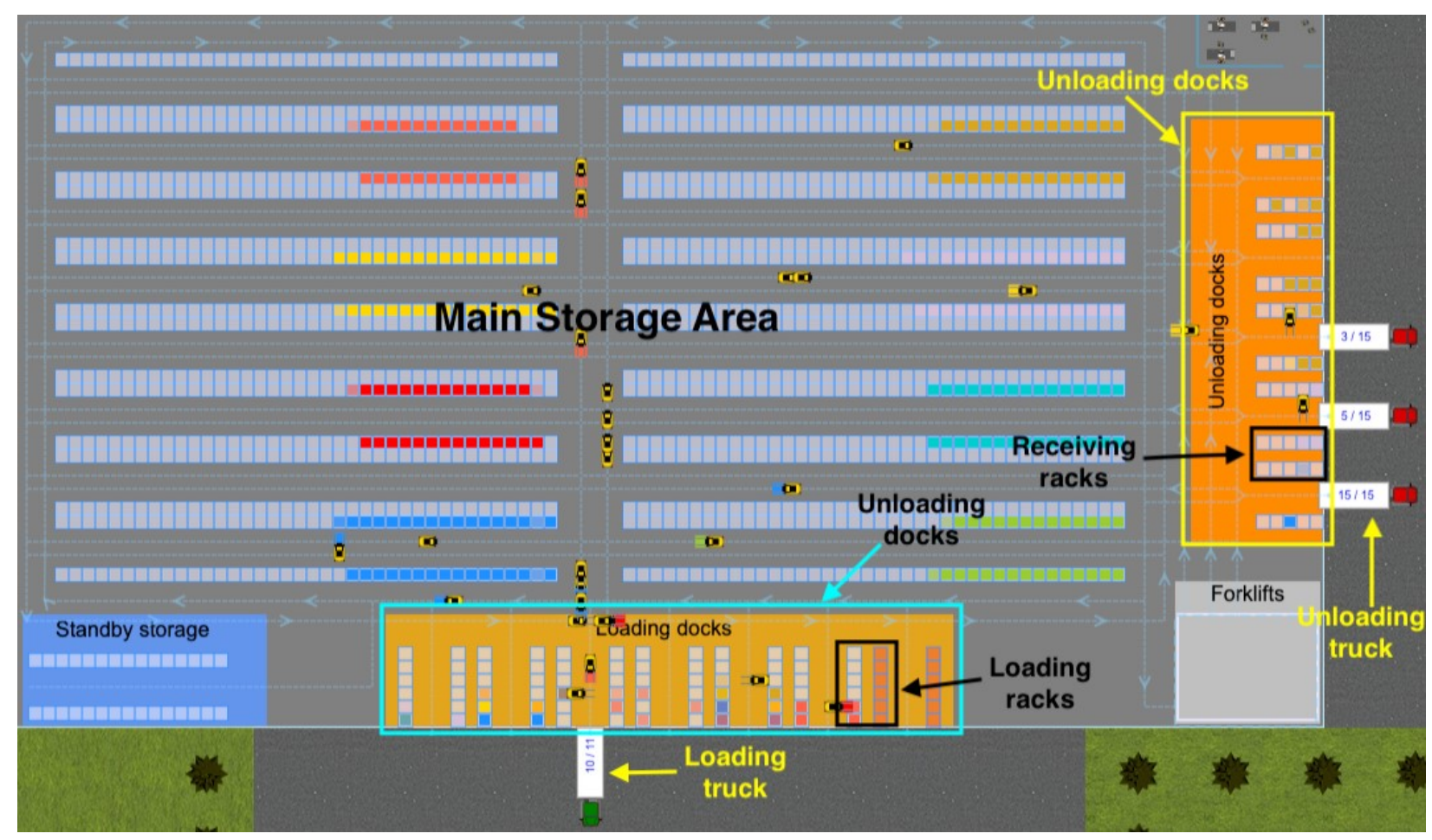




\section{Simulation Description}

The simulation has its underlying logic in order to represent the processes in the distribution center. Figure 3 shows the logic of the simulation where the unloading and loading processes represented using the simulation blocks such as queues and delays. The assembly process is embedded into loading process. Also, the "initial filling of the storage" represents placing the pallets in the main storage area. The other two processes, such as "moving from the storage to a moving dock", and "moving from a standby storage to a moving dock" represent placing the assembled pallets in the loading dock area. Every block in the logic represents an event. For example, the block "truckUnloading" is the event of forklifts unloading the pallets from trucks. The pallets as the main target of the production at the distribution center go through multiple events which all together represent the entire operation process. Also, the input data used in the logic are represented by different parameters shown in figure 4. Some important parameters are:

- Unloading rate (7)- approximately 7 unloading trucks arrive at the center per hour.

- Loading rate (3)- approximately 3 loading trucks arrive at the center per hour.

- Order rate (3)- approximately 3 orders are placed per hour. Each order quantity is between 10 and 14 .

- Number of unloading docks (5)- There are 5 unloading docks.

- Number of loading docks (6)- There are 6 loading docks.

- Number of forklifts (20)- There are 20 forklifts in the center (May change based on different scenarios). 
Figure 3: Details of the simulation logic of the distribution center

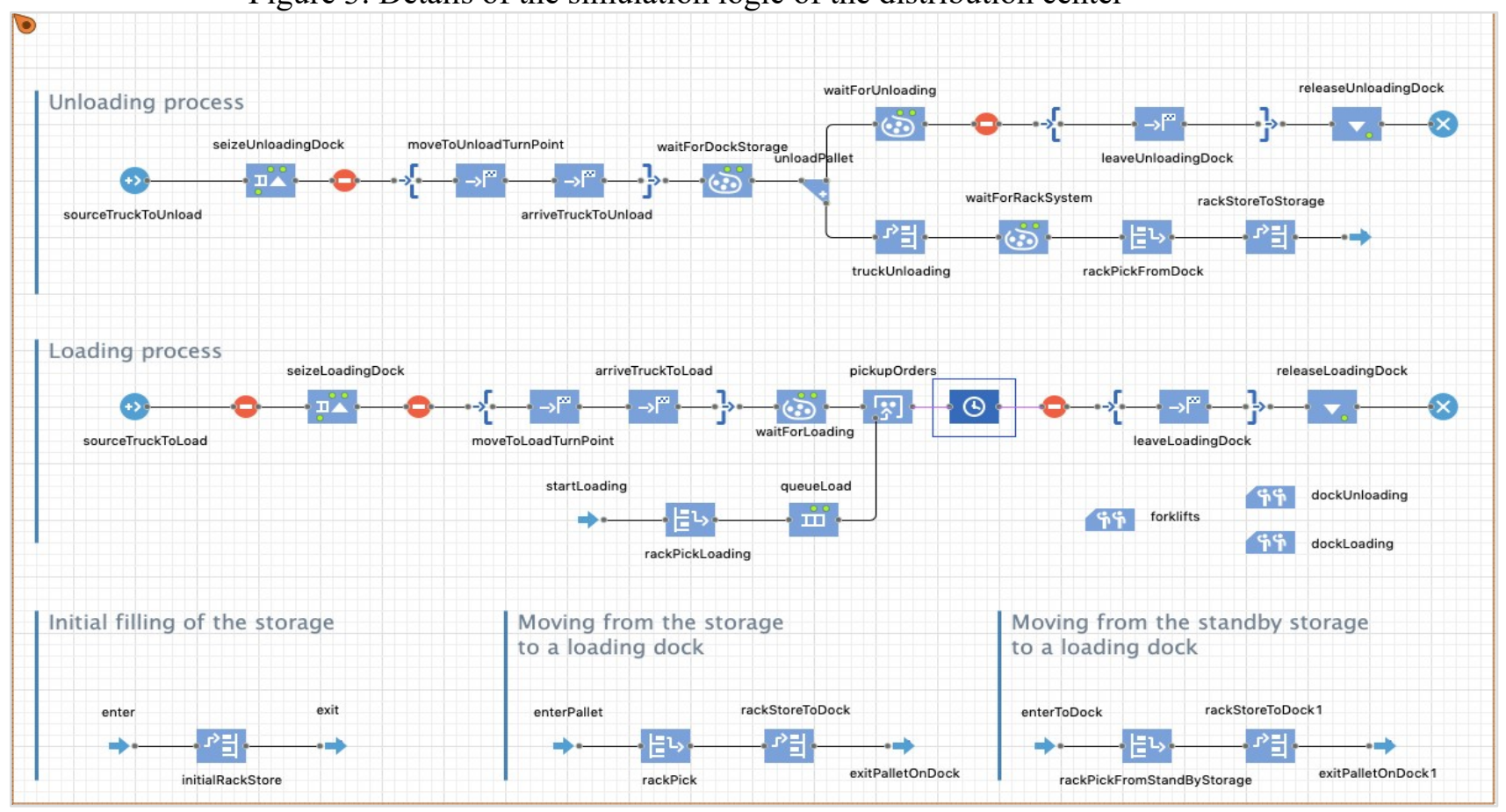

Figure 4: Parameters in the simulation
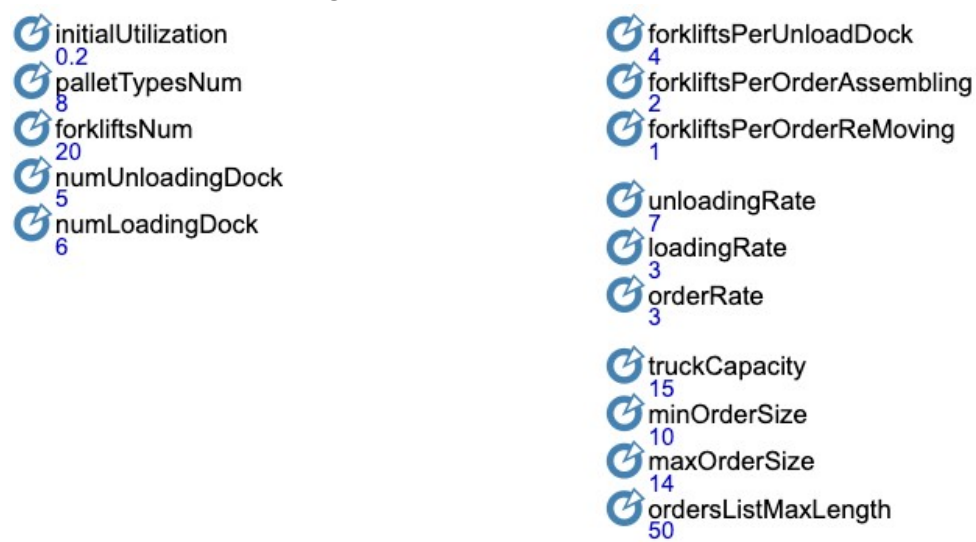

There are two parts of dependability analysis conducted in the case study. In Part A, FMEA is applied first to analyze the processes to evaluate possible failures in the system, the causes of the failures, effects, RPN, and future actions. After this is finished, its limitations are discussed. In Part B, as comparison, the discrete event simulation method is applied to explore the same processes in three 
different levels. In this part, the simulation outcome is utilized to showcase how the discrete event simulation can enhance FMEA's capability.

\section{FMEA On Distribution Center: Phase A}

In this part, a detailed FMEA analysis of the distribution center is described. As a first step, the processes should be studied carefully in order to distinguish the possible failures. There are three main phases to focus on for the evaluation of various potential failures. As shown in Table 1, the processes of the distribution center are divided into 1) the unloading phase; 2) the assembling phase; and 3) the loading phase. And each phase relies on a few critical operational resources such as trucks, forklifts, and pallets for the processes to operate as intended.

Table 1: Main Phases and Related Critical Resources, and Process Details

\begin{tabular}{|c|c|c|c|}
\hline Main Phases & Phase 1 & Phase 2 & Phase 3 \\
\hline $\begin{array}{l}\text { Critical } \\
\text { Resources }\end{array}$ & Unloading & Assembling & Loading \\
\hline $\begin{array}{l}\text { Unloading trucks } \\
\text { Loading trucks } \\
\text { Forklifts } \\
\text { Pallets } \\
\text { Pallet Racks }\end{array}$ & $\begin{array}{l}\text { The distribution center } \\
\text { receives pallets } \\
\text { delivered by trucks. } \\
\text { Pallets are then } \\
\text { unloaded from the } \\
\text { trucks using forklifts } \\
\text { and placed in the } \\
\text { receiving dock area. } \\
\text { After this, other } \\
\text { forklifts move the } \\
\text { pallets to the main } \\
\text { storage area. }\end{array}$ & $\begin{array}{l}\text { Orders from distribution } \\
\text { center's clients are } \\
\text { assembled from same or } \\
\text { different types of pallets } \\
\text { by forklifts accordingly } \\
\text { and placed in the } \\
\text { loading area. }\end{array}$ & $\begin{array}{l}\text { After the orders are } \\
\text { assembled, a truck is } \\
\text { assigned to the loading } \\
\text { dock. Then forklifts } \\
\text { will load the pallets into } \\
\text { the truck. }\end{array}$ \\
\hline
\end{tabular}

After the preliminary understanding of the processes in the distribution center, the second step is to evaluate possible failures, the causes of the failures, their effects, and the current controls, and calculate 
the risk priority number (RPN) related to the critical resources over different phases. As the last step, the action priorities are determined based on the RPN values and suggested future actions are provided to prevent the identified failures from happening, hence the processes could be enhanced over time.

RPN is calculated based on the ratings of severity, occurrence, and detection. RPN is the product of these elements. The rating approach in this research is shown in table 2, 3, and 4.

Table 2: Ratings for The Severity of a Failure (Andrejić and Kilibarda, 2017)

\begin{tabular}{|c|c|c|}
\hline Rating & Effect & Severity of effect \\
\hline 10 & $\begin{array}{l}\text { Hazardous without } \\
\text { warning }\end{array}$ & $\begin{array}{l}\text { Very high severity ranking when a potential failure mode effects safe or } \\
\text { effective system operation }\end{array}$ \\
\hline 9 & $\begin{array}{l}\text { Hazardous with } \\
\text { warning }\end{array}$ & $\begin{array}{l}\text { Very high severity ranking when a potential failure mode affects safe or } \\
\text { effective system operation }\end{array}$ \\
\hline 8 & Very high & $\begin{array}{l}\text { System operates ineffectively with destructive failure without } \\
\text { compromising safety }\end{array}$ \\
\hline 7 & High & System operates without efficiency \\
\hline 6 & Moderate & System operates with minor damage and deficiency \\
\hline 5 & Low & System operates with minor deficiency \\
\hline 4 & Very low & System operates with significant degradation of performance \\
\hline 3 & Minor & System operates with some degradation of performance \\
\hline 2 & Very minor & System operates with minimal interference \\
\hline 1 & None & No effect \\
\hline
\end{tabular}

Table 3: Ratings for The Occurrence of a Failure (Andrejić and Kilibarda, 2017)

\begin{tabular}{|l|l|l|}
\hline Rating & Probability of occurrence & Failure probability \\
\hline 10 & Very high: failure is almost inevitable & $>1$ in 2 \\
\hline 9 & & 1 in 3 \\
\hline 8 & High: repeated failures & 1 in 8 \\
\hline 7 & & 1 in 20 \\
\hline 6 & Moderate: occasional failures & 1 in 80 \\
\hline 5 & & 1 in 400 \\
\hline 4 & & 1 in 2000 \\
\hline 3 & Low: relatively few failures & 1 in 15,000 \\
\hline 2 & & 1 in 150,000 \\
\hline 1 & Remote: failure is unlikely & $<1$ in $1,500,000$ \\
\hline
\end{tabular}


Table 4: Ratings for The Detection (Andrejić and Kilibarda, 2017)

\begin{tabular}{|l|l|l|}
\hline Rating & Detection & Likelihood of detection by current control \\
\hline 10 & Absolute uncertainty & Current control cannot detect potential cause \\
\hline 9 & Very remote & Very remote chance the current control will detect potential cause \\
\hline 8 & Remote & Remote chance the current control will detect potential cause \\
\hline 7 & Very low & Very low chance the current control will detect potential cause \\
\hline 6 & Low & Low chance the current control will detect potential cause \\
\hline 5 & Moderate & Moderate chance the current control will detect potential cause \\
\hline 4 & Moderately high & Moderately high chance the current control will detect potential cause \\
\hline 3 & High & High chance the current control will detect potential cause \\
\hline 2 & Very high & Very high chance the current control will detect potential cause \\
\hline 1 & Almost certain & Current control will detect potential cause \\
\hline
\end{tabular}

Table 5 shows a section of the complete FMEA analysis related to the failures to do with the forklift resource (The entire FMEA analysis is included in the Appendix). Under the "Forklifts" category, there are several sub-categories of what could go wrong and its more specific failure items are identified. For example, as highlighted with the red line, under the "Amount of Forklifts", "Less than needed" is identified as one of its possible failures. The assumption in this analysis is that there are 20 forklifts in the center, and they are not enough to operate center efficiently. With that, for this possible failure, "Insufficient understanding of daily need for forklifts" is listed as a cause of the failure. Then, "A: May cause longer operation time. Hence, may delay the orders", "B: May cause stress for employees", and "C: May Shorten forklifts' lifetime" are assessed as the effects of the failure. After establishing these, RPN is calculated to be 96 based on the level of perception of the occurrence, severity, and detection of the effects of the failure. The RPN value (240) is higher with respect to other failure items, which justifies the Action Priority as "Urgent". As a result, a Suggested Action, "Try to understand the need for forklifts based on the order flow and adjust the amount", is recommended to prevent the perceived failure. This analysis is called "Analysis A" in order to be compared with further analysis using discrete event simulation in later sessions. 
Table 5: Example of Analysis A

Failure Modes \& Effects Analysis on Distribution Center

\begin{tabular}{|c|c|c|c|c|c|c|c|c|c|c|c|}
\hline Category & Sub-category & Possible Failure & Cause of the failure & Effects of the failure & Severerity & Occurance & Detection & Current Control & RPN & Action Priorty & Suggested Action \\
\hline Forkilits & $\begin{array}{l}\text { Amount of } \\
\text { Forkifits }\end{array}$ & Less than needed & $\begin{array}{l}\text { Insufficient } \\
\text { understanding of daily } \\
\text { need for forklifts }\end{array}$ & $\begin{array}{l}\text { A:May cause longer } \\
\text { opreration time. Hence, } \\
\text { may delay the orders. } \\
\text { B: May cause stress for } \\
\text { employees. } \\
\text { C: May Shorten forklifts' } \\
\text { lifetime. }\end{array}$ & 8 & 5 & 6 & $\begin{array}{c}\text { Inspecting } \\
\text { Forklift Utilization }\end{array}$ & 240 & Urgent & $\begin{array}{l}\text { Try to understand the } \\
\text { need for forkifits based } \\
\text { on the order flow, and } \\
\text { adjust the amount. }\end{array}$ \\
\hline
\end{tabular}

FMEA's inherent deficiencies can be seen from Analysis A. First, Analysis A is a subjective analysis. This may be the vital disadvantage of FMEA. During the FMEA approach, one of the main challenges is that it relies on tacit knowledge and opinions heavily. This may result in different or inconsistent outcomes from the FMEA analysis. This could be significant because when calculating the RPN, the subjective opinions and inputs heavily influences how the severity, occurrence, and detection are determined. One may have totally different views on all these elements than others. One may assess the severity of the less forklifts to be 6 and others may consider it to be 9 , which could produce a large deviation in the RPN value, which results in quite different action priority and therefore the suggested actions are taken more seriously or less seriously. Since organizations rank their future actions based on action priorities, this type of subjective analysis of FMEA may lead to possible economic loss and magnify the problems in the system even bigger.

Second, FMEA is not able to create comparison analysis to Analysis A. If we assume there are 30 forklifts in the system now and see what difference it could make using FMEA, it is not possible to conduct an "what if" scenario analysis. This is because when Analysis A is conducted, there is not any quantitative or scenario to support it. This results in evaluating the impact of the failure mode without any foundation. Without foundation, it is not possible to conduct comparison analysis. Its inability to create quantitative comparison analysis makes it difficult to understand the system behavior in depth. Therefore, 
it may be difficult to make proper decisions to optimize the overall system performance for the long-term by using FMEA. The example is given in table 6 .

Table 6: FMEA Based Comparison Analysis (FMEA's Inability to Conduct "What If" Scenarios)

\begin{tabular}{|c|c|}
\hline Original FMEA analysis & $\begin{array}{cl}\text { Analysis A (20 forklifts): } \\
\text { - } & \text { Severity: } 8 \\
\text { - } & \text { Occurrence: } 5 \\
\text { - } & \text { Detection: } 6 \\
\text { - } & \text { RPN: } 240\end{array}$ \\
\hline Comparison FMEA analysis & $\begin{array}{c}\text { Analysis A (30 forklifts): } \\
\text { - Severity: ? } \\
\text { - Occurrence: ? } \\
\text { - Detection: ? } \\
\text { - RPN: ? }\end{array}$ \\
\hline
\end{tabular}

Third, FMEA could possibly miss possible failures all together. This may happen because, during the FMEA, entire operation process is not visualized, and hidden effects cannot be identified as well. There may be possibilities for the FMEA participant to overlook some small but important aspects of the process in the evaluation, especially if it is a new and complex system. In addition to that, if any subtle changes happen in the processes, the effects of these changes are hard to detect since there is no direct way to measure the impact of the changes in FMEA. This may also result in another possible failures not considered in the analysis.

In summary, FMEA is a strong operation improvement tool to enhance the system performance by eliminating the potential reasons of the system failure, it is based on the subjective assessment of the failures and is not able to create comparison analysis. On the other hand, in reality these failures are not isolated cases but rather they are often entangled with each other. One failure, small or large, may have come from another one issue, and may produce subsequent failures down the line of the processes. 


\section{Discrete Event Simulation on Distribution Center: Phase B}

To improve FMEA's deficiencies discussed in the earlier sessions, discrete event simulation is conducted on distribution center using the same failure mode- "Amount of Forklift"- analyzed by FMEA. The statistical outcome from the simulation is applied to analyze the system behavior. Furthermore, there are three levels of analysis in this session. They are compared with Analysis A from FMEA and with other analysis later on. In addition, there are three KPIs used to analyze the impact of the failure. They are "forklifts utilization", "order assembling mean waiting time", and "free main storage space". In level one, forklifts utilization is applied to analyze the impact of the failure. In level two, forklifts utilization plus order assembling mean waiting time is applied. In level three, all three KPIs are applied together. More importantly, in each level there are two different scenarios as comparison analysis. Scenario one is 20 forklifts, scenario two is 30 forklifts. All KPI combinations are used in each scenario separately to identify which condition may enhance the distribution center's performance. The whole process of analysis in this session is to create a conceptual algorithm to show how discrete event simulation can enhance FMEA.

\section{Level 1- One KPI}

In level one, the "forklifts utilization" is applied as KPI. "forklifts utilization" is the result of forklifts being used at the moment divided by the forklifts amount. The KPI is applied for two different scenarios, which are 20 forklifts in the center, and 30 forklifts in the center. An assumption is made in level 1 to better utilize the simulation outcome. It is assumed that "forklifts utilization expected" to be $90 \%$ at most in order to keep the remaining $10 \%$ for emergency. With that figure 5 shows the "forklifts

utilization" result when there are 20 forklifts in the center, and it is $100 \%$. That means all the forklifts are 
being used, but no forklifts left for emergency. So, it can be concluded that when there are 20 forklifts in the center, all of them are operating without being idle. But, there is not ant forklifts for emergency use. So, the RPN from the Analysis A can be modified. The severity is modified from 8 to 7 . The occurrence remains the same as 5 . The detection is changed from 6 to 3 because of the fact that discrete event simulation's outcome can help better detect the failures. Hence, the new severity is 7 , occurrence is 5 , detection is 3 , and RPN is 105 . This analysis is called "Analysis B".

Figure 5: Forklifts utilization- Analysis B (20 forklifts)

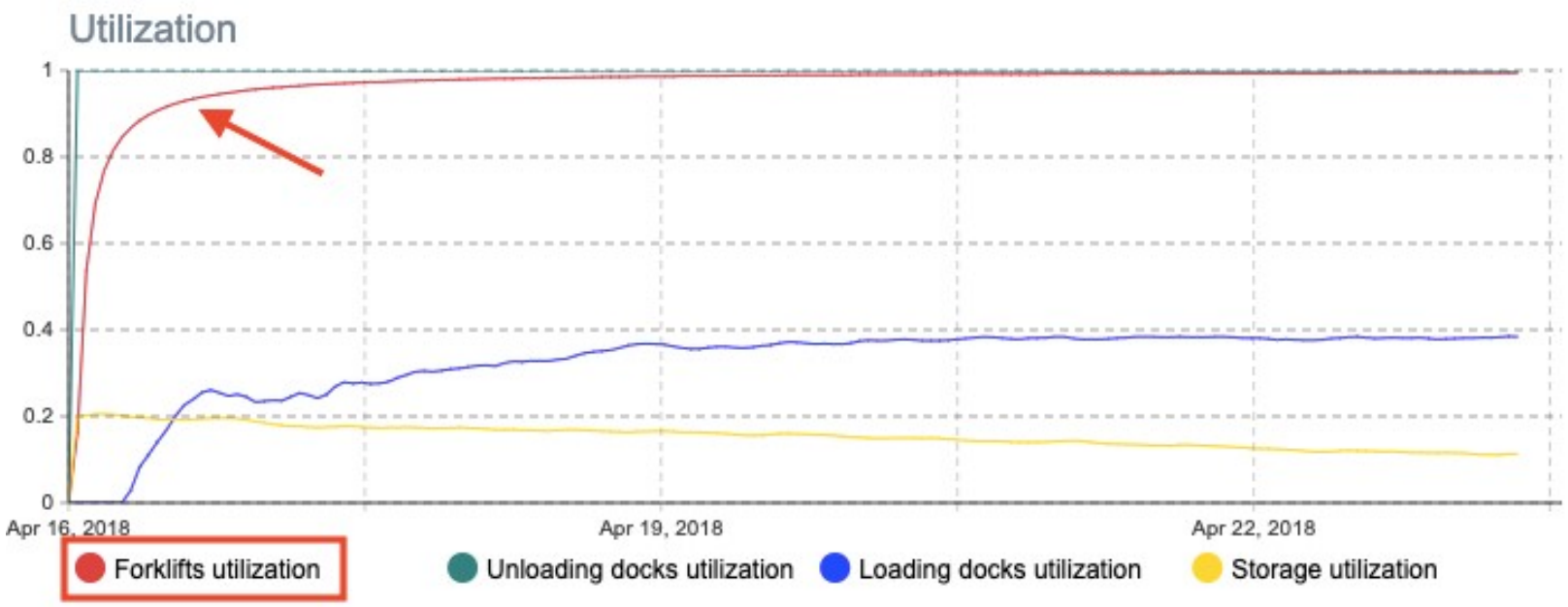

To make a comparison analysis and better understand the system performance, the scenario of 30 forklifts in the center is analyzed. The same assumption is applied in this scenario. The figure 6 shows the outcome when there are 30 forklifts in the center. The "forklifts utilization" is still $100 \%$ without having forklifts for emergency. It can be concluded that when there are 30 forklifts in the center, all of them are being utilized with no extra forklifts for future emergencies. Therefore, the 30 forklifts are not enough when other variables are static. Since the outcome is very similar to Analysis B, the RPN and other elements remain the same. They are, severity 7, occurrence 5, detection 3, and RPN 105. This analysis is called "Analysis B". The first phase conceptual algorithm is shown in table 7. 
Figure 6: Forklifts utilization- Analysis B`(30 forklifts)

\section{Utilization}

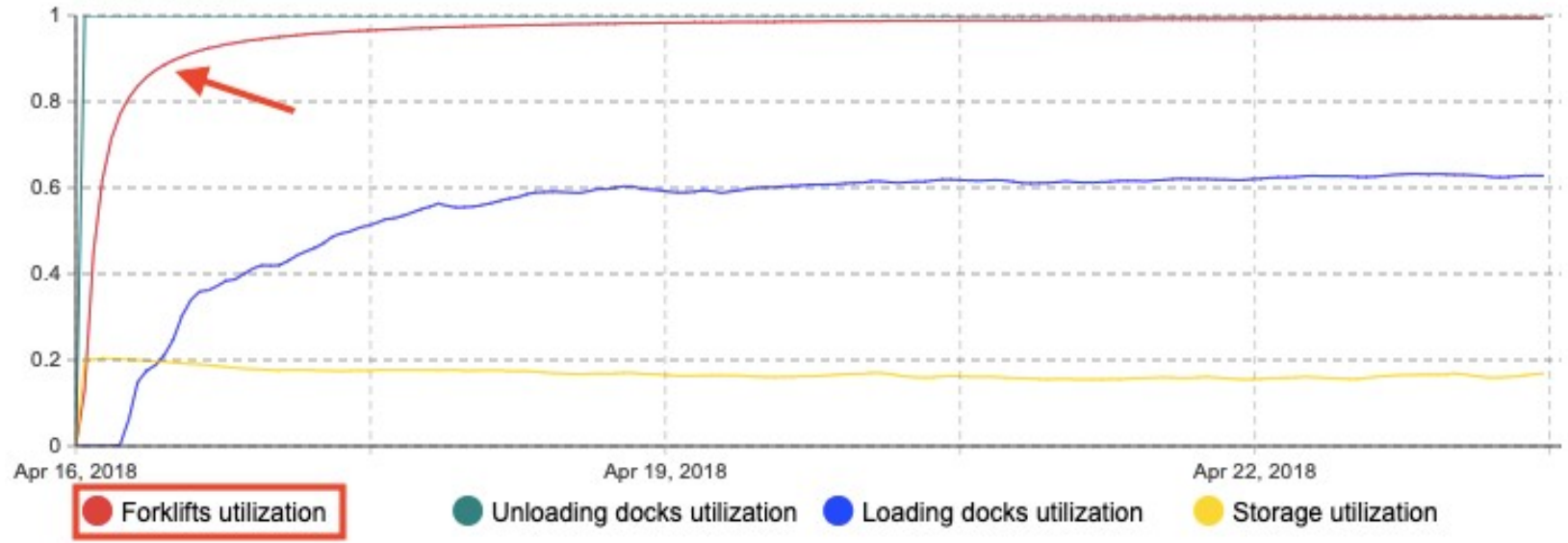

Table 7: 1st Phase of Step by Step Analysis Development to Improve FMEA Via Simulation (Illustration Using Forklift Amount in Warehouse Operation)

\begin{tabular}{|l|l|}
\hline \multicolumn{1}{|c|}{ FMEA } & \multicolumn{1}{|c|}{ Discrete Event Simulation } \\
\hline Analysis A (20 forklifts): & Analysis B (20 forklifts, 1 KPI): \\
- Severity: 8 & - Severity: 7 \\
- Occurrence: 5 & - Occurrence: 5 \\
- Detection: 6 & - Retection: 3 \\
- RPN: 240 & \\
\hline Analysis A` (30 forklifts): 105 \\
- Severity: ? & Analysis B` (30 forklifts, 1 KPI): \\
- Occurrence: ? & - Severity: 7 \\
- Detection: ? & - Decurrence: 5 \\
- RPN: ? & - RPN: 105 \\
\hline
\end{tabular}

\section{Level 2- Two KPIs}

In level 2, two KPIs are used. They are "forklifts utilization" and "Order Assembling Mean Waiting Time". Order assembling mean waiting time is the between when an order is placed and when the order is completely assembled, and forklifts' efficiency has a strong impact on it. Assumption for this criterion is that order assembling waiting time cannot be greater than 5 minutes. With that, figure 7 shows the forklifts utilization and assembling waiting time when there are 20 forklifts in the center. The result 
shows that the assembling mean waiting time is more than 10 minutes and it is twice greater than expected waiting time. Now, it can be concluded that although all the forklifts are being utilized, order assembling mean waiting time is still twice greater than expectation. The RPN can be modified based on this conclusion. The severity is 9 , occurrence is 5 , detection is 3 , and RPN is 135 . This analysis is called “Analysis C”.

Figure 7: Analysis C- forklifts utilization \& order assembling mean waiting time (20 forklifts) Utilization
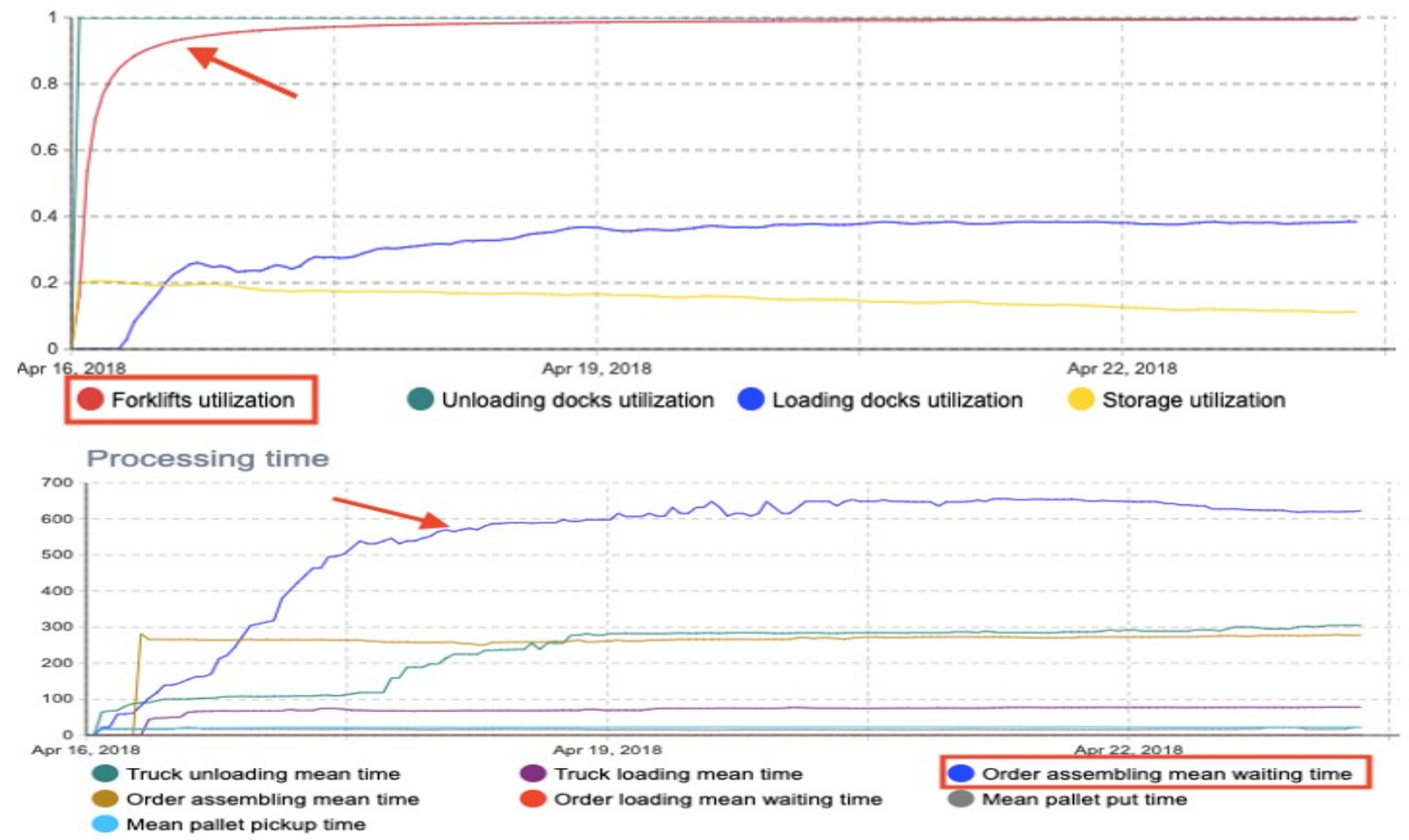

Same KPIs are applied for new analysis- "Analysis C"”- as comparison to Analysis C. There are 30 forklifts in the center in new analysis. The expectation for order assembling mean waiting time is still the same, which is 5 minutes. The figure 8 is the result for forklifts utilization and order assembling mean waiting time when there are 30 forklifts in the center. The data shows that the waiting time is between 3.3 minutes to 4.2 minutes and that is within the expectation. The performance regarding the assembly time is improved significantly. The conclusion can be although all the forklifts are being utilized without leaving 
$10 \%$ for emergency, the order assembly waiting time meets requirement and is improved. Therefore, the RPN can be modified. The new severity is 6 , occurrence is 5 , detection is 3 , and

RPN in 90. The table 8 is the second phase of conceptual algorithm.

Figure 8: Analysis C'- forklifts utilization \& order assembling mean waiting time (30 forklifts) Utilization

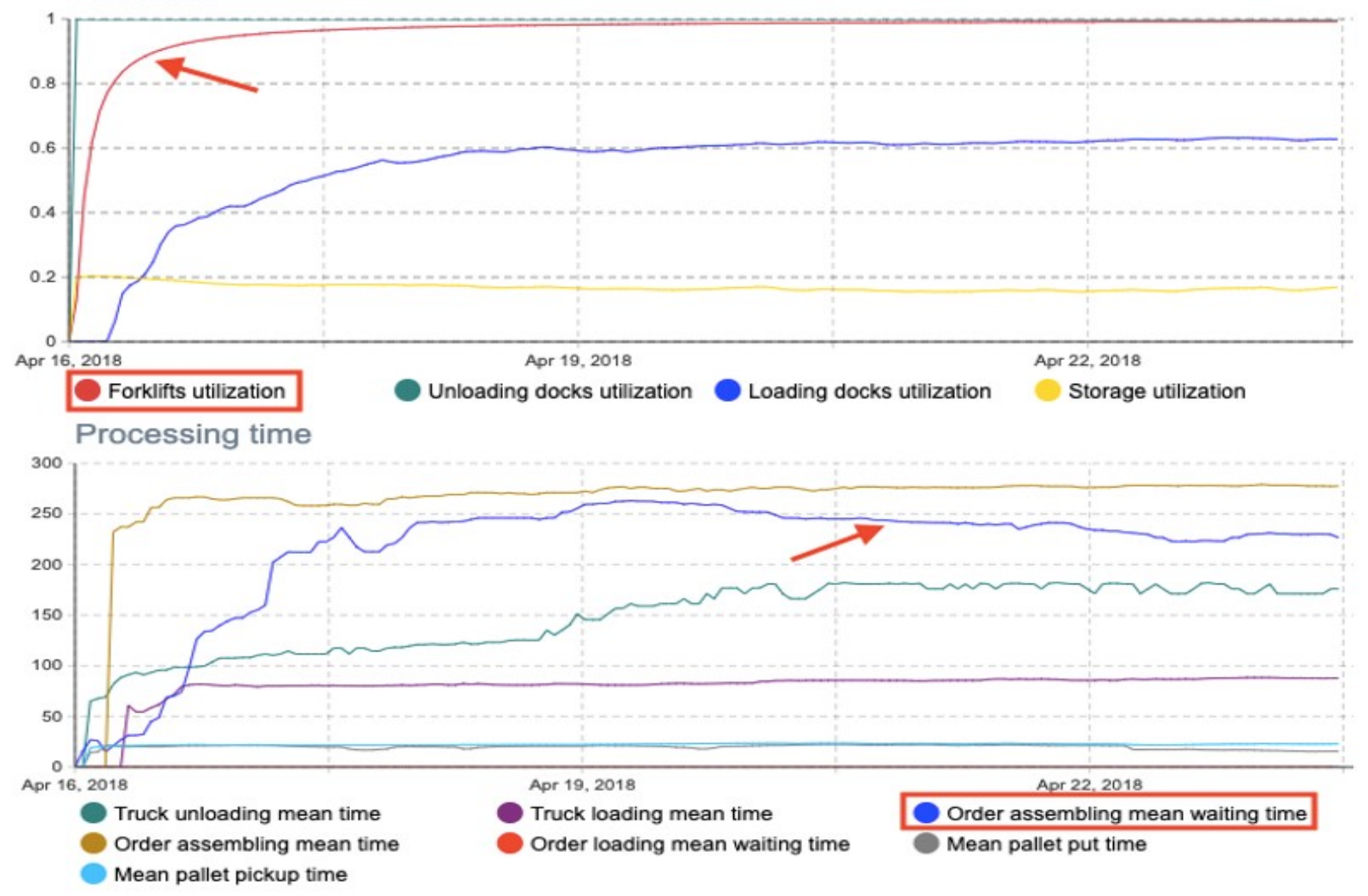

Table 8: 2nd Phase of Step by Step Analysis Development to Improve FMEA Via Simulation (Illustration Using Forklift Amount in Warehouse Operation)

\begin{tabular}{|c|c|c|}
\hline \multicolumn{1}{|c|}{ FMEA Analysis } & \multicolumn{2}{|c|}{ Discrete Event Simulation } \\
\hline Analysis A (20 forklifts): & Analysis B (20 forklifts, 1 KPI): & Analysis C (20 forklifts, 2 \\
- Severity: 8 & - Severity: 7 & KPIs): \\
- Occurrence: 5 - Occurrence: 5 & - Severity: 9 \\
Detection: 6 & - Detection: 3 & - Occurrence: 5 \\
RPN: 240 & - RPN: 105 & - Retection: 3 \\
& & RPN: 135 \\
\hline
\end{tabular}




\begin{tabular}{|c|c|c|}
\hline $\begin{array}{c}\text { Analysis A` (30 forklifts): } \\
\text { - Severity: ? } \\
\text { - Occurrence: ? } \\
\text { - Detection:? } \\
\text { - RPN: ? }\end{array}$ & 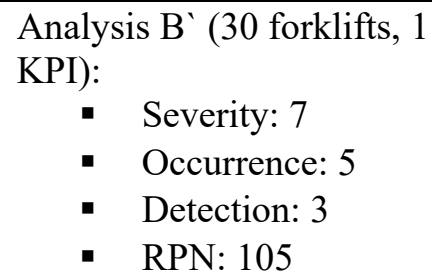 & $\begin{array}{l}\text { Analysis C` }(30 \text { forklifts, } 2 \\
\text { KPIs): } \\
\text { - Severity: } 6 \\
\text { - Occurrence: } 5 \\
\text { - } \text { Detection: } 3 \\
\text { - RPN: } 90\end{array}$ \\
\hline
\end{tabular}

Level 3- Three KPIs

In level 3, there are three KPIs. The newly added KPI is "free main storage space". The reason this KPI is chosen is because main storage space can have an impact on forklifts efficiency. Similarly, the combination of three KPIs are applied in two different scenarios separately. The assumption for the "free main storage space" is that there should be at least $80 \%$ of free space for forklifts to transport efficiently. With that, the figure 9 illustrates the result when there are 20 forklifts in the center. The new information is that there are $88 \%$ of free space when there are 20 forklifts in the center. Therefore, it can be inferred that although order assembling mean waiting time does not meet the requirement when forklifts utilization is $100 \%$, the distribution center has enough space for forklifts' transportation. The previous RPN can be modified. The new severity is 8 , occurrence is 5 , detection is 3 , and RPN is 120 . This analysis is called “Analysis D". 
Figure 9: Analysis D- forklifts utilization \& order assembling mean waiting time \& free main storage space (20 forklifts)
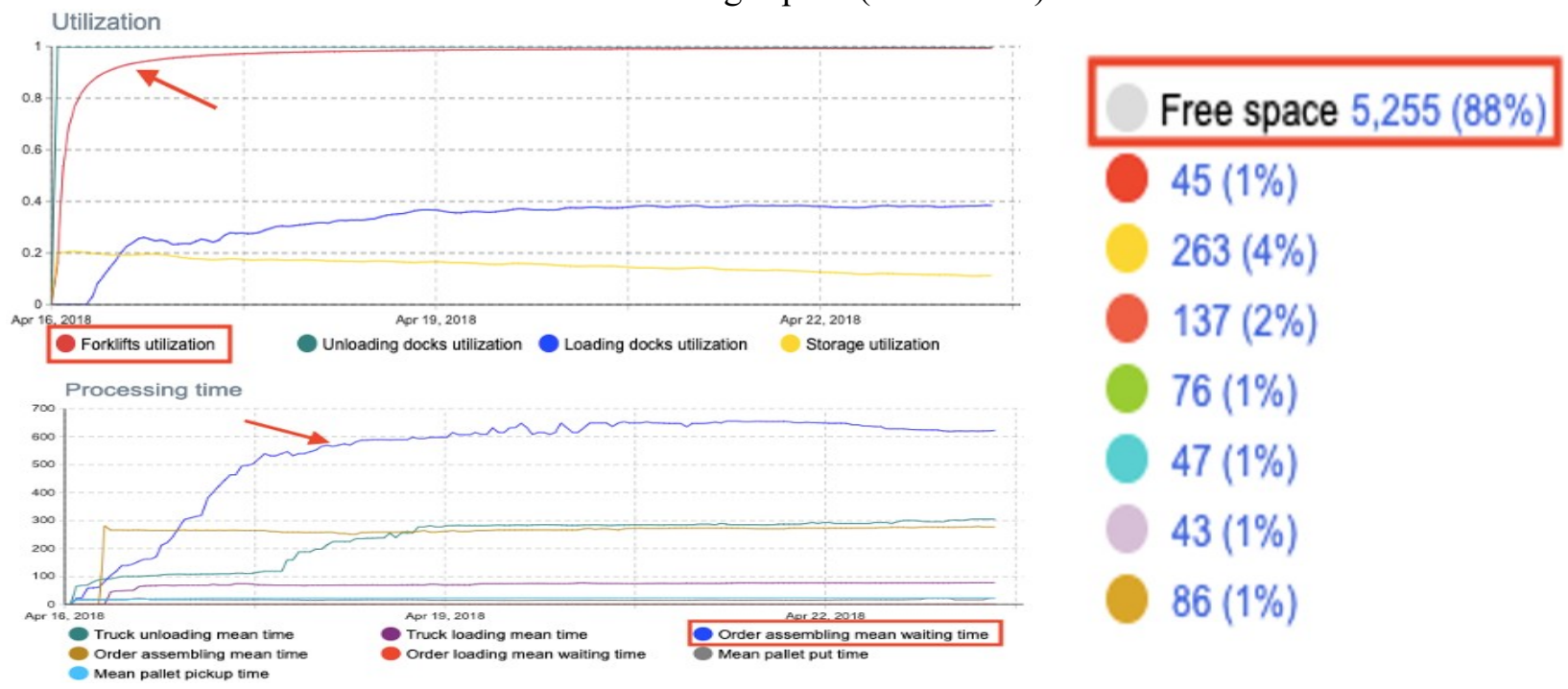

Analysis D'- when there are 30 forklifts in the center- is done as a comparison to Analysis D and other analysis. Same KPIs and assumptions in Analysis D are applied in the new analysis. The figure 10 shows the result when there are 30 forklifts operating in the center. This time, the free space is $84 \%$. It is also within the expectation. Additionally, the order assembling mean waiting time and forklifts utilization are same as previous scenarios when there were 30 forklifts in the center. Hence, it can be concluded that although all the forklifts are being utilized, order assembling mean waiting time, and free main storage space are within the expectation. The RPN can be modified based on new outcome. The new severity is 5 , occurrence is 5 , detection is 3 , and RPN is 75 . The final phase of conceptual algorithm is given in table 6 . 
Figure 10: Analysis D`- forklifts utilization \& order assembling mean waiting time \& free main storage space (30 forklifts)
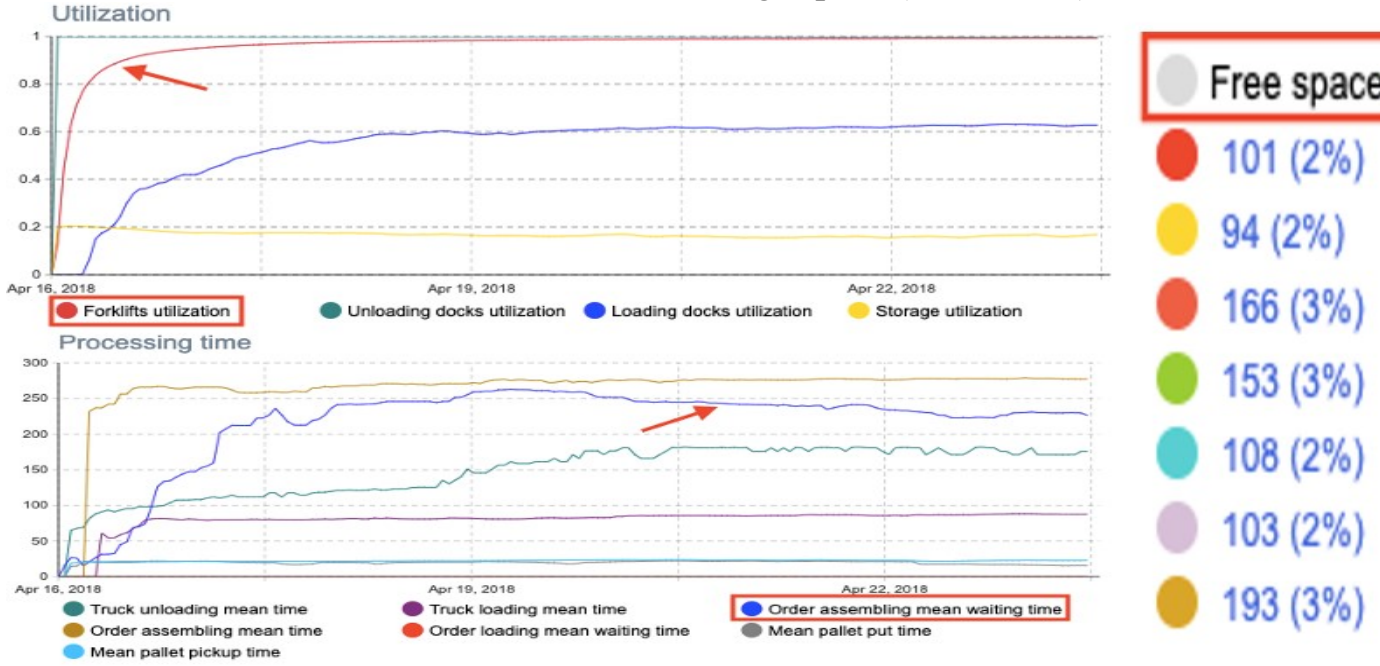

Table 9: 3rd Phase of Step by Step Analysis Development to Improve FMEA Via Simulation (Illustration using Forklift Amount in Warehouse Operation)

\begin{tabular}{|c|c|c|c|}
\hline FMEA analysis & \multicolumn{3}{|c|}{ Discrete Event Simulation } \\
\hline $\begin{array}{l}\text { Analysis A }(20 \\
\text { forklifts): } \\
\text { - Severity: } 8 \\
\text { - Occurrence: } 5 \\
\text { - } \quad \text { Detection: } 6 \\
\text { - } \quad \text { RPN: } 240\end{array}$ & $\begin{array}{l}\text { Analysis B (20 } \\
\text { forklifts, } 1 \mathrm{KPI}) \text { : } \\
\text { - } \quad \text { Severity: } 7 \\
\text { - } \quad \text { Occurrence: } 5 \\
\text { - } \quad \text { Detection: } 3 \\
\text { - } \quad \text { RPN: } 105\end{array}$ & $\begin{array}{l}\text { Analysis C (20 } \\
\text { forklifts, } 2 \text { KPIs): } \\
\text { - } \quad \text { Severity: } 9 \\
\text { Occurrence: } 5 \text { - } \\
\text { Detection: } 3 \\
\text { - } \quad \text { RPN: } 135\end{array}$ & $\begin{array}{l}\text { Analysis D (20 } \\
\text { forklifts, } 3 \text { KPIs): } \\
\text { - } \quad \text { Severity: } 9 \\
\text { Occurrence: } 5 \text { - } \\
\text { Detection: } 3 \\
\text { - } \quad \text { RPN: } 135\end{array}$ \\
\hline $\begin{array}{l}\text { Analysis A` }(30 \\
\text { forklifts): } \\
\text { - Severity: ? } \\
\text { - Occurrence: ? } \\
\text { - Detection:? } \\
\text { - RPN:? }\end{array}$ & $\begin{array}{l}\text { Analysis B` }(30 \\
\text { forklifts, } 1 \mathrm{KPI}) \text { : } \\
\text { - } \quad \text { Severity: } 7 \\
\text { - } \quad \text { Occurrence: } 5 \\
\text { - } \quad \text { Detection: } 3 \\
\text { - } \quad \text { RPN: } 105\end{array}$ & $\begin{array}{l}\text { Analysis C' }(30 \\
\text { forklifts, } 2 \text { KPIs): } \\
\text { - } \text { Severity: } 6 \\
\text { - } \text { Occurrence: } 5 \\
\text { - } \text { Detection: } 3 \\
\text { - } \quad \text { RPN: } 90\end{array}$ & $\begin{array}{l}\text { Analysis D` }(30 \\
\text { forklifts, } 3 \text { KPIs): } \\
\text { - Severity: } 6 \\
\text { - Occurrence: } 5 \\
\text { - } \quad \text { Detection: } 3 \\
\text { - RPN: } 90\end{array}$ \\
\hline
\end{tabular}


Summary on Discrete Event Simulation

After applying discrete event simulation to analyze the failure mode in distribution center, it can be seen that simulation can provide evidentiary data and stronger cause-effect analysis capacity that FMEA lacks. Another advantage discrete event simulation has is that it can visualize the whole operation which is helpful to discover as many failure modes as possible.

More importantly, applying the step by step approach in the case study, discrete event simulation is even more helpful to understand the dynamic of the system using RPN score. The table 6 shows the step by step analysis from "Analysis A" to "Analysis D"'. Through RPN scores in the table, performance of the distribution center is better learned using different environment and different KPIs. The whole process offers more thorough and deeper analysis. Also, based on the change and stabilization of the RPN score, it can be seen that FMEA's analysis capability is enhanced. The chart 1 and 2 show the RPN's change and stabilization along with step by step analysis. In each chart, it can be seen that starting from the DES (1 KPI) RPN scores change drastically and their range is within a linear trend. So, it indicates along with better understanding of the system using discrete event simulation, the original FMEA's result is improved and stabilized. The point where RPN score changes drastically or starts being linear trend can be considered as FMEA enhancement point. This could also be applied in different cases as well. 
Figure 11: RPN stabilized point using KPI (20 forklifts)

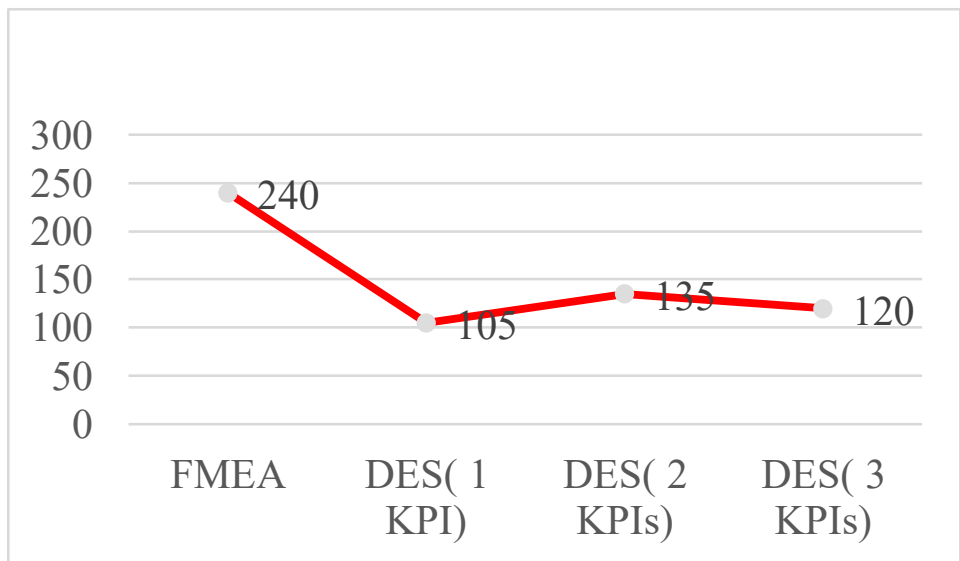

Figure 12: RPN stabilized point using KPI (30 forklifts)

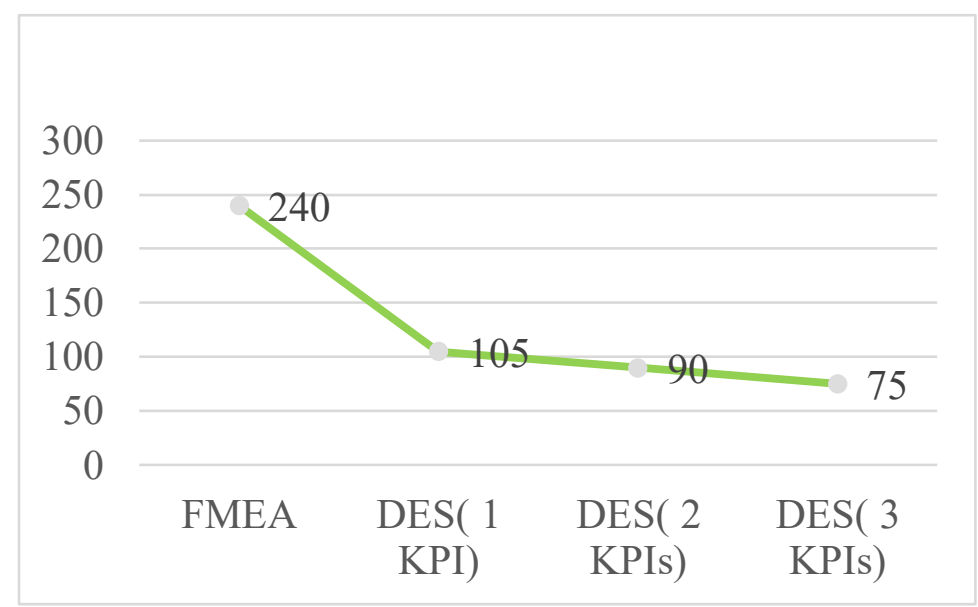




\section{CHAPTER VI: CONCLUSION}

FMEA is a widely applied Six Sigma tool for process and product optimization. However, it has some inherited drawbacks. In this research, after reviewing abundant literature regarding FMEA's enhancement, its remaining deficiencies are identified, which are subjective analysis and lack of causeeffect analysis capability. Then, discrete event simulation is introduced as a tool to improve FMEA. By using a case study, a step by step analysis approach using different KPIs and scenarios was demonstrated in order to showcase how discrete event simulation can enhance FMEA.

After applying discrete event simulation, FMEA's subjectivity and cause-effect analysis capability is significantly improved. This is due to Discrete Event Simulation quantifies the FMEA's rating approach for Severity, Occurrence, and Detection of a failure mode. FMEA becomes more accountable after relying on simulation result instead of subjective understanding. This can result in better identifying the underlying risks in the system and identifying the solution for them. On the other hand, the step by step analysis with different KPIs and in different scenarios provided a new insight to understand the dynamics of the system. Table 10 shows the generalized step by step analysis approach. In the table, using different combination of KPI(s) and different scenarios, each analysis can tell us different story about the system. This can help better understand the failure modes and system performance under different conditions. Such an approach can be applied on other failure modes using specific KPIs and scenarios in various domains. 
Table 10: Generalized Step by Step Analysis Approach

\begin{tabular}{|c|c|c|c|}
\hline FMEA analysis & \multicolumn{3}{|c|}{ Discrete Event Simulation } \\
\hline $\begin{array}{l}\text { Analysis A (Scenario } \\
\text { A): } \\
\text { - } \quad \text { Severity: } a \\
\text { - Occurrence: b } \\
\text { - } \\
\text { - } \\
\text { Detection: c } \\
\text { RPN: abc }\end{array}$ & $\begin{array}{l}\text { Analysis B (Scenario A, } \\
1 \text { KPI): } \\
\text { - Severity: a' } \\
\text { - Occurrence: b' } \\
\text { - Detection: c' } \\
\text { - RPN: abc' }\end{array}$ & $\begin{array}{l}\text { Analysis C (Scenario A, } \\
2 \text { KPIs): } \\
\text { - Severity: a" } \\
\text { - Occurrence: b", } \\
\text { - Detection: c", } \\
\text { - RPN: abc" }\end{array}$ & $\begin{array}{l}\text { Analysis D (Scenario A, n } \\
\text { KPIs): } \\
\text { - Severity: a", } \\
\text { - Occurrence: b", } \\
\text { - Detection: c", } \\
\text { - RPN: abc", }\end{array}$ \\
\hline $\begin{array}{l}\text { Analysis A` (Scenario } \\
\text { B): } \\
\text { - } \quad \text { Severity: } x \\
\text { - Occurrence: } y \\
\text { - } \\
\text { - } \\
\text { Detection: } z \\
\text { RPN: } x y z\end{array}$ & $\begin{array}{l}\text { Analysis B' (Scenario B, } \\
\text { 1 KPI): } \\
\text { - Severity: x' } \\
\text { - Occurrence: y' } \\
\text { - Detection: z' } \\
\text { - RPN: xyz' }\end{array}$ & $\begin{array}{l}\text { Analysis C' (Scenario B, } \\
2 \text { KPIs): } \\
\text { - Severity: x", } \\
\text { - Occurrence: y" } \\
\text { - Detection: z" } \\
\text { - RPN: xyz" }\end{array}$ & $\begin{array}{l}\text { Analysis D' (Scenario B, } \\
\text { n KPIs): } \\
\text { - Severity: x",, } \\
\text { - Occurrence: y", } \\
\text { - Detection: z", } \\
\text { - RPN: xyz", }\end{array}$ \\
\hline
\end{tabular}

Furthermore, RPN scores fluctuates along with analysis as well. However, there will be a point from which the original RPN score from FMEA changes drastically or starts to be stable in an approximately linear trend. This point can be considered as a reference point for FMEA's enhancement. Chart 3 shows generalized RPN stabilized point. Through stabilized RPN score trend, cause-effect of failures can be analyzed in depth, and more suitable corrective actions may be revealed from the analysis process. Such a trend can also be an indication for either further analysis or moving onto next step in which future corrective mitigations are discussed.

Figure 13: Generalized RPN stabilized Point

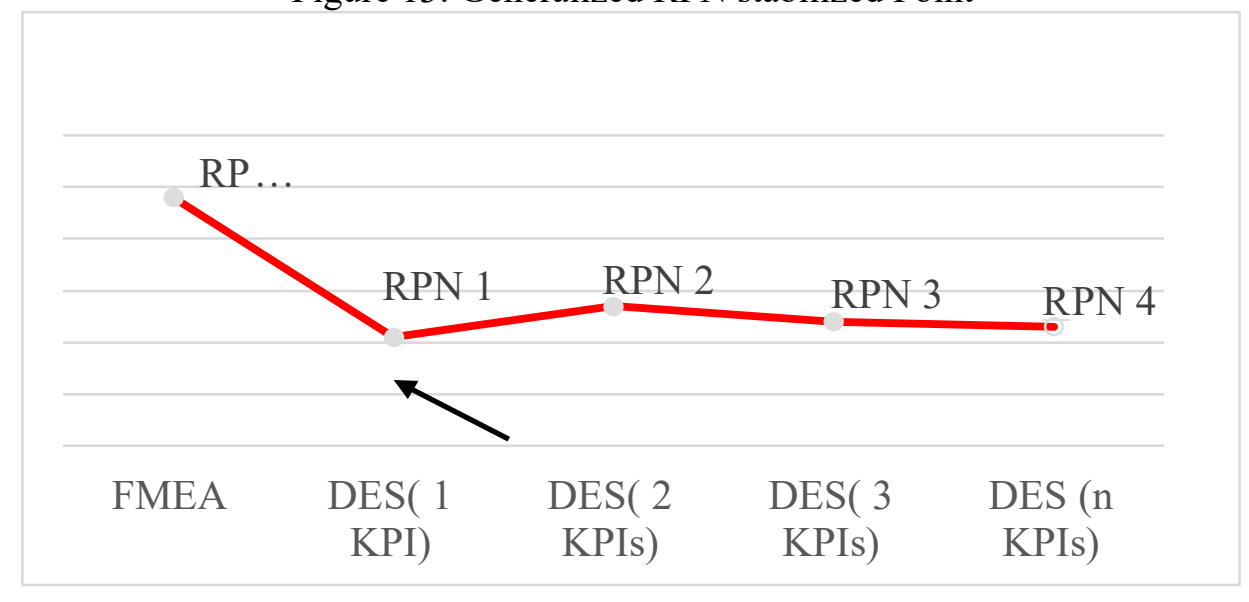


Finally, by applying discrete event simulation with FMEA, the whole analysis can be more qualitative and objective. Discrete event simulation's strong evidentiary data can also strengthen the cause-effect capability of FMEA. More importantly, the generalized step by step approach using simulation, can provide more prospective and insights to optimize the various real-life system behavior. 


\section{CHAPTER VII: FUTURE STUDIES}

The distribution center model in this research is a pre-existed model. Therefore, there is a limitation to prove the effectiveness of the proposed method. To overcome that, researches on applying the method on a real-life scenario can be done in order to validate the effectiveness of the step by step analysis approach.

On the other hand, to create a discrete event simulation, well understanding of the processes and components is needed. So, by providing more qualitative insights to design a simulation in the first place, it may be possible for FMEA to improve discrete event simulation's accuracy. With that, future researches can be done to explore FMEA's ability to enhance discrete event simulation's outcome. This may help simulation industry to improve their work efficiency and sustainability for the long term as well. 


\section{REFERENCES}

Andrejić, M., \& Kilibarda, M. (2017). Failure management in distribution logistics applying FMEA approach. In Proceedings of the 3nd International Logistics conference (pp. 148-153).

Banks, J., J.S. Carson. (1986). WSC '86: Proceedings of the 18th conference on Winter simulation(Vol. 211, pp. 17-23) (Banks, J., J. S. Carson, Author; J. R. Wilson \& J. O. Henrikson, Eds.). New York, NY: Association for Computing Machinery. doi: $10.1145 / 318242.318253$

BERG, S. (2010). Water utility benchmarking: Measurement, methodologies, and performance incentives. London: Iwa Publishing.

Chang, D., \& Sun, K. P. (2009). Applying DEA to enhance assessment capability of FMEA. International Journal of Quality \& Reliability Management, 26(6), 629643.doi:10.1108/02656710910966165

Dillibabu, R., \& Krishnaiah, K. (2006). Application of Failure Mode and Effects Analysis to Software Code Reviews A Case Study. Software Quality Professional Magazine, 8.

Doshi, J., \& Desai, D. (2017). Application of failure mode \& effect analysis (FMEA) for continuous quality improvement - multiple case studies in automobile SMEs. International Journal for Quality Research,11, 345-360. doi:10.18421/IJQR11.02-07

Hekmatpanah, M. (2011). The application of cause and effect diagram in the oil industry in Iran: The case of four liter oil canning process of Sepahan Oil Company. African Journal of Business Management,5(26). doi:10.5897/ajbm11.1517 
Jacobson S.H., Hall S.N., Swisher J.R. (2006) Discrete-Event Simulation of Health Care Systems. In: Hall R.W. (eds) Patient Flow: Reducing Delay in Healthcare Delivery. International Series in Operations Research \& Management Science, vol 91. Springer, Boston, MA. https://doi.org/10.1007/978-0-387-33636-7_8

Liu, H., You, J., Ding, X., \& Su, Q. (2015). Improving risk evaluation in FMEA with a hybrid multiple criteria decision making method. International Journal of Quality \& Reliability Management, 32(7), 763-782. doi:10.1108/ijqrm-10-2013-0169

Misra, J. (1986). Distributed discrete-event simulation. ACM Computing Surveys, 18(1), 39-65. doi:10.1145/6462.6485

Murphy, M., Heaney, G., \& Perera, S. (2011). A methodology for evaluating construction innovation constraints through project stakeholder competencies and FMEA. Construction Innovation,11(4), 416-440. doi:10.1108/14714171111175891

Parks, Jennifer Kaye; Engblom, Patricia; Hamrock, Eric; Satjapot, Siriporn; Levin, Scott PhD Designed to Fail: How Computer Simulation Can Detect Fundamental Flaws in Clinic Flow, Journal of Healthcare Management: March-April 2011 - Volume 56 - Issue 2 - p 135-146

Peeters, J., Basten, R., \& Tinga, T. (2018). Improving failure analysis efficiency by combining FTA and FMEA in a recursive manner. Reliability Engineering \& System Safety, 172, 36-44. doi:10.1016/j.ress.2017.11.024

Raunak, M., Osterweil, L., Wise, A., Clarke, L., \& Henneman, P. (2009). Simulating patient flow through an Emergency Department using process-driven discrete event simulation. 2009 ICSE Workshop on Software Engineering in Health Care. doi:10.1109/sehc.2009.5069608 
Seyed-Hosseini, S., Safaei, N., \& Asgharpour, M. (2006). Reprioritization of failures in a system failure mode and effects analysis by decision making trial and evaluation laboratory technique. Reliability Engineering \& System Safety, 91(8), 872-881. doi:10.1016/j.ress.2005.09.005

Scipioni, A., Saccarola, G., Centazzo, A., \& Arena, F. (2002). FMEA methodology design, implementation and integration with HACCP system in a food company. Food Control,13(8), 495-501. doi:10.1016/s0956-7135(02)00029-4

Shaker, F., Shahin, A., \& Jahanyan, S. (2019). Developing a two-phase QFD for improving FMEA: an integrative approach. International Journal of Quality \& Reliability Management, 36(8), 14541474.

Spreafico, C., Russo, D., \& Rizzi, C. (2017). A state-of-the-art review of FMEA/FMECA including patents. Computer Science Review, 25, 19-28. doi:10.1016/j.cosrev.2017.05.002

Sumari, S., Ibrahim, R., Zakaria, N. H., \& Hamid, A. H. (2013). Comparing Three Simulation Model Using Taxonomy: System Dynamic Simulation, Discrete Event Simulation and Agent Based Simulation. International Journal of Management Excellence,1(3), 54. doi:10.17722/ijme.v1i3.9

Sutrisno, A., Kwon, H. M., Gunawan, I., Eldridge, S., \& Lee, T. R. (2016). Integrating SWOT analysis into the FMEA methodology to improve corrective action decision making. International Journal of Productivity and Quality Management, 17(1), 104. doi:10.1504/ijpqm.2016.073283

Wohlgemuth, V., Page, B., \& Kreutzer, W. (2006). Combining discrete event simulation and material flow analysis in a component-based approach to industrial environmental protection. Environmental Modelling \& Software,21(11), 1607-1617. doi:10.1016/j.envsoft.2006.05.015 


\section{APPENDIX (COMPLETE FMEA ANALYSIS)}

Table 3: Complete FMEA analysis on distribution center Failure Modes \& Effects Analysis on Distribution Center

\begin{tabular}{|c|c|c|c|c|c|c|c|c|c|c|c|}
\hline Category & Sub-category & Possible Failure & Cause of the failure & Effects of the failure & Severerity & Occurance & Detection & Current Control & RPN & Action Priorty & Suggested Action \\
\hline \multirow{5}{*}{ Forklifts } & $\begin{array}{l}\text { Amount of } \\
\text { Forklifts }\end{array}$ & Less than needed & $\begin{array}{l}\text { Insufficient } \\
\text { understanding of daily } \\
\text { need for forklifts }\end{array}$ & $\begin{array}{l}\text { A:May cause longer } \\
\text { opreration time. Hence, } \\
\text { may delay the orders. } \\
\text { B: May cause stress for } \\
\text { employees. } \\
\text { C: May Shorten forklifts' } \\
\text { lifetime. }\end{array}$ & 8 & 5 & 6 & $\begin{array}{l}\text { Inspecting } \\
\text { Forklift } \\
\text { Utilization }\end{array}$ & 240 & Urgent & $\begin{array}{l}\text { Try to understand the } \\
\text { need for forklifts based } \\
\text { on the order flow, and } \\
\text { adjust the amount. }\end{array}$ \\
\hline & \multirow{2}{*}{$\begin{array}{l}\text { Speed of } \\
\text { Forklifts }\end{array}$} & Overspeed & Driving too fast & $\begin{array}{l}\text { May cause safety } \\
\text { problem during the } \\
\text { operation time. }\end{array}$ & 7 & 4 & 2 & $\begin{array}{c}\text { Visual } \\
\text { inspection }\end{array}$ & 56 & Relatively High & $\begin{array}{l}\text { Train employees } \\
\text { regulary and emphasize } \\
\text { the both safety, and } \\
\text { work efficiency. }\end{array}$ \\
\hline & & Underspeed & Driving too slow & $\begin{array}{l}\text { May cause longer } \\
\text { operation time, hence } \\
\text { may delay the orders. }\end{array}$ & 7 & 4 & 4 & $\begin{array}{c}\text { Visual } \\
\text { inspection }\end{array}$ & 112 & Urgent & $\begin{array}{l}\text { Train employees } \\
\text { regularly and emphasize } \\
\text { the both safety, and } \\
\text { work efficiency. }\end{array}$ \\
\hline & $\begin{array}{c}\text { Maintenance of } \\
\text { Forklifts }\end{array}$ & $\begin{array}{c}\text { Damages during the } \\
\text { operation }\end{array}$ & $\begin{array}{l}\text { Fail to maintain } \\
\text { regularly }\end{array}$ & $\begin{array}{l}\text { A: May cause safety } \\
\text { problem during the } \\
\text { operation } \\
\text { B: May cause longer } \\
\text { operation time, hence } \\
\text { may delay the orders } \\
\text { C: May shorten the } \\
\text { forklifts' lifetime } \\
\text { D: May increase } \\
\text { maintenance cost }\end{array}$ & 7 & 3 & 5 & $\begin{array}{c}\text { Regular } \\
\text { maintenance }\end{array}$ & 105 & Urgent & $\begin{array}{l}\text { Follow the regular } \\
\text { maintenance. Also, } \\
\text { implement monitering } \\
\text { solution for it. }\end{array}$ \\
\hline & Forklift Dock & Unproportioned space & $\begin{array}{l}\text { Wrong decision over } \\
\text { space for forklifts }\end{array}$ & $\begin{array}{l}\text { A: May cause poor } \\
\text { utilization of forklifts (if } \\
\text { the space is } \\
\text { insufficient) } \\
\text { B: May increase } \\
\text { unnecessary waste of } \\
\text { space }\end{array}$ & 6 & 2 & 2 & $\begin{array}{c}\text { Visual } \\
\text { inspection }\end{array}$ & 24 & Low & $\begin{array}{l}\text { Adjust the space for } \\
\text { forklift dock based on } \\
\text { analyzing the current } \\
\text { amount of forklifts and } \\
\text { space. }\end{array}$ \\
\hline
\end{tabular}

\begin{tabular}{|c|c|c|c|c|c|c|c|c|c|c|c|}
\hline Category & Sub-category & Possible Failure & Cause of the failure & Effects of the failure & Occurance & Severerity & Detection & Current Control & RPN & Action Priorty & Suggested Action \\
\hline \multirow[b]{2}{*}{$\begin{array}{l}\text { Unloading } \\
\text { Docks }\end{array}$} & \multirow[b]{2}{*}{$\begin{array}{l}\text { Number of } \\
\text { Docks }\end{array}$} & More than needed & $\begin{array}{l}\text { Insufficient } \\
\text { understanding of order } \\
\text { flow }\end{array}$ & $\begin{array}{l}\text { A: May Cause } \\
\text { unnecessary waste of } \\
\text { space } \\
\text { B: May increase } \\
\text { unnecessary } \\
\text { management cost. }\end{array}$ & 4 & 5 & 2 & $\begin{array}{c}\text { Visual } \\
\text { inspection }\end{array}$ & 40 & Relatively High & $\begin{array}{l}\text { Analyze the order flow, } \\
\text { and adjust the number } \\
\text { of docks based on it. }\end{array}$ \\
\hline & & Less than needed & $\begin{array}{l}\text { Insufficient } \\
\text { understanding of order } \\
\text { flow }\end{array}$ & $\begin{array}{l}\text { A: May cause longer } \\
\text { unloading time, hence } \\
\text { may delay the orders. } \\
\text { B: May cause stress to } \\
\text { employees due to } \\
\text { pressure from } \\
\text { unloading process. }\end{array}$ & 4 & 7 & 2 & $\begin{array}{c}\text { Visual } \\
\text { inspection }\end{array}$ & 56 & Relatively High & $\begin{array}{l}\text { Analyze the order flow, } \\
\text { and adjust the number } \\
\text { of docks based on it. }\end{array}$ \\
\hline
\end{tabular}




\begin{tabular}{|c|c|c|c|c|c|c|c|c|c|c|c|}
\hline & \multirow[b]{2}{*}{$\begin{array}{l}\text { Space of } \\
\text { Docks }\end{array}$} & More than needed & $\begin{array}{l}\text { Wrong decision on } \\
\text { space for docks }\end{array}$ & $\begin{array}{l}\text { A: May cause } \\
\text { unnecessary waste of } \\
\text { space. } \\
\text { B: May increase } \\
\text { unnecessary } \\
\text { management cost. }\end{array}$ & 2 & 5 & 2 & $\begin{array}{c}\text { Visual } \\
\text { inspection }\end{array}$ & 20 & Low & $\begin{array}{l}\text { Analyze the order flow, } \\
\text { pallet flow, and adjust } \\
\text { the sapce of docks } \\
\text { based on it. }\end{array}$ \\
\hline & & Less than needed & $\begin{array}{l}\text { Wrong decision on } \\
\text { space for docks }\end{array}$ & $\begin{array}{l}\text { A: There will not be } \\
\text { enough space for } \\
\text { palletRacks, hence } \\
\text { may cause longer } \\
\text { unloading time. } \\
\text { B: May cause stress to } \\
\text { employees. }\end{array}$ & 3 & 6 & 3 & $\begin{array}{c}\text { Visual } \\
\text { inspection }\end{array}$ & 54 & Relatively High & $\begin{array}{l}\text { Analyze the order flow, } \\
\text { pallet flow, and adjust } \\
\text { the sapce of docks } \\
\text { based on it. }\end{array}$ \\
\hline \multirow{4}{*}{$\begin{array}{l}\text { Loading } \\
\text { Docks }\end{array}$} & \multirow[b]{2}{*}{$\begin{array}{l}\text { Number of } \\
\text { Docks }\end{array}$} & More than needed & $\begin{array}{l}\text { Insufficient } \\
\text { understanding of order } \\
\text { flow }\end{array}$ & $\begin{array}{l}\text { A: Causes } \\
\text { unnecessary waste of } \\
\text { space } \\
\text { B: May increase } \\
\text { unnecessary } \\
\text { management cost. }\end{array}$ & 2 & 5 & 2 & $\begin{array}{c}\text { Visual } \\
\text { inspection }\end{array}$ & 20 & Low & $\begin{array}{l}\text { Analyze the order flow, } \\
\text { and adjust the number } \\
\text { of docks based on it. }\end{array}$ \\
\hline & & Less than needed & $\begin{array}{l}\text { Insufficient } \\
\text { understanding of order } \\
\text { flow }\end{array}$ & $\begin{array}{l}\text { A: May cause longer } \\
\text { loading time, hence } \\
\text { may delay the orders. } \\
\text { B: May cause stress to } \\
\text { employees due to } \\
\text { pressure from loading } \\
\text { process. }\end{array}$ & 3 & 7 & 2 & $\begin{array}{c}\text { Visual } \\
\text { inspection }\end{array}$ & 42 & Relatively High & $\begin{array}{l}\text { Analyze the order flow, } \\
\text { and adjust the number } \\
\text { of docks based on it. }\end{array}$ \\
\hline & \multirow[b]{2}{*}{$\begin{array}{l}\text { Space of } \\
\text { Docks }\end{array}$} & More than needed & $\begin{array}{l}\text { Wrong decision on } \\
\text { space for docks }\end{array}$ & $\begin{array}{l}\text { A: May cause } \\
\text { unnecessary waste of } \\
\text { space. } \\
\text { B: May increase } \\
\text { unnecessary } \\
\text { management cost. }\end{array}$ & 4 & 5 & 2 & $\begin{array}{c}\text { Visual } \\
\text { inspection }\end{array}$ & 40 & Relatively High & $\begin{array}{l}\text { Analyze the order flow } \\
\text { and adjust the sapce of } \\
\text { docks based on it. }\end{array}$ \\
\hline & & Less than needed & $\begin{array}{l}\text { Wrong decision on } \\
\text { space for docks }\end{array}$ & $\begin{array}{l}\text { A: There will not be } \\
\text { enough space for } \\
\text { palletRacks, hence } \\
\text { may cause longer } \\
\text { loading time. } \\
\text { B: May cause stress } \\
\text { to employees. C: May } \\
\text { delay the orders. } \\
\text { D: May cause } \\
\text { overreliance on } \\
\text { standby storage. }\end{array}$ & 4 & 7 & 2 & $\begin{array}{c}\text { Visual } \\
\text { inspection }\end{array}$ & 56 & Relatively High & $\begin{array}{l}\text { Analyze the order flow } \\
\text { and adjust the sapce of } \\
\text { docks based on it. }\end{array}$ \\
\hline
\end{tabular}

\begin{tabular}{|c|c|c|c|c|c|c|c|c|c|c|c|}
\hline Category & $\begin{array}{l}\text { Sub- } \\
\text { category }\end{array}$ & Possible Failure & Cause of the failure & $\begin{array}{l}\text { Effects of the } \\
\text { failure }\end{array}$ & Occurance & Severerity & Detection & \begin{tabular}{|l} 
Current \\
Control \\
\end{tabular} & RPN & Action Priorty & Suggested Action \\
\hline \multirow{4}{*}{$\begin{array}{l}\text { Unloading } \\
\text { Trucks }\end{array}$} & \multirow{2}{*}{$\begin{array}{c}\text { Capacity of } \\
\text { Unloading } \\
\text { Trucks }\end{array}$} & More than needed & $\begin{array}{l}\text { Decided by the } \\
\text { manufacturer }\end{array}$ & $\begin{array}{l}\text { A: May cause } \\
\text { overinventory B: } \\
\text { May increase } \\
\text { management cost } \\
\text { due to over- } \\
\text { inventory }\end{array}$ & 3 & 6 & 3 & $\begin{array}{c}\text { Manufacturer's } \\
\text { responsibility }\end{array}$ & 54 & $\begin{array}{l}\text { Relatively } \\
\text { High }\end{array}$ & $\begin{array}{l}\text { Based on the order } \\
\text { flow, give } \\
\text { manufacturer } \\
\text { feedback to adjust } \\
\text { truck capacity. }\end{array}$ \\
\hline & & Less than needed & $\begin{array}{l}\text { Decided by the } \\
\text { manufacturer }\end{array}$ & $\begin{array}{l}\text { A: May decrease } \\
\text { the work } \\
\text { efficiency. B: } \\
\text { May delay the } \\
\text { orders. }\end{array}$ & 3 & 7 & 3 & $\begin{array}{c}\text { Manufacturer's } \\
\text { responsibility }\end{array}$ & 63 & High & $\begin{array}{l}\text { Based on the order } \\
\text { flow, give } \\
\text { manufacturer } \\
\text { feedback to adjust } \\
\text { truck capacity. }\end{array}$ \\
\hline & $\begin{array}{c}\text { Maintenance } \\
\text { of Unloading } \\
\text { Trucks }\end{array}$ & $\begin{array}{l}\text { Damages during } \\
\text { the delivery }\end{array}$ & $\begin{array}{l}\text { The manufacturer } \\
\text { fails to maintain } \\
\text { regularly }\end{array}$ & 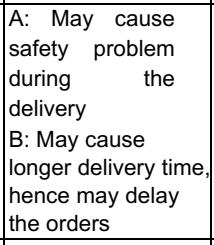 & 2 & 7 & 2 & $\begin{array}{c}\text { Manufacturer's } \\
\text { responsibility }\end{array}$ & 28 & Low & $\begin{array}{l}\text { Give feedback to } \\
\text { the manufacturer }\end{array}$ \\
\hline & $\begin{array}{c}\text { Amount of } \\
\text { Unloading } \\
\text { Trucks }\end{array}$ & Less than needed & $\begin{array}{l}\text { Decided by the } \\
\text { manufacturer }\end{array}$ & $\begin{array}{l}\text { May delay the } \\
\text { orders. }\end{array}$ & 4 & 7 & 4 & $\begin{array}{c}\text { Manufacturer's } \\
\text { responsibility }\end{array}$ & 112 & Urgent & $\begin{array}{l}\text { Based on the order } \\
\text { flow, give } \\
\text { manufacturer } \\
\text { feedback to adjust } \\
\text { the amount of } \\
\text { trucks they } \\
\text { possess. }\end{array}$ \\
\hline
\end{tabular}




\begin{tabular}{|c|c|c|c|c|c|c|c|c|c|c|c|}
\hline \multirow{5}{*}{$\begin{array}{l}\text { Loading } \\
\text { Trucks }\end{array}$} & \multirow[b]{2}{*}{$\begin{array}{c}\text { Capacity of } \\
\text { Loading } \\
\text { Trucks }\end{array}$} & More than needed & $\begin{array}{l}\text { Insufficient } \\
\text { understanding of } \\
\text { order flow }\end{array}$ & 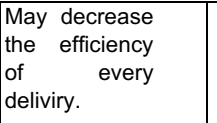 & 3 & 6 & 2 & N/A & 36 & $\begin{array}{l}\text { Relatively } \\
\text { High }\end{array}$ & $\begin{array}{lr}\text { Based } & \text { on the } \\
\text { order } & \text { flow, } \\
\text { adjust } & \text { truck } \\
\text { capacity. } & \end{array}$ \\
\hline & & Less than needed & $\begin{array}{l}\text { Insufficient } \\
\text { understanding of } \\
\text { order flow }\end{array}$ & $\begin{array}{l}\text { A: May delay the } \\
\text { orders. } \\
\text { B: May increase } \\
\text { unnecessary truck } \\
\text { utilization } \\
\text { C: May cause extra } \\
\text { purchase of trucks }\end{array}$ & 3 & 7 & 2 & N/A & 42 & $\begin{array}{l}\text { Relatively } \\
\text { High }\end{array}$ & $\begin{array}{l}\text { Based on the } \\
\text { order flow, adjust } \\
\text { truck capacity or } \\
\text { purchase new } \\
\text { trucks. }\end{array}$ \\
\hline & \multirow[b]{2}{*}{$\begin{array}{l}\text { Amount of } \\
\text { Loading } \\
\text { Trucks }\end{array}$} & More than needed & $\begin{array}{l}\text { Insufficient } \\
\text { understanding of } \\
\text { order flow }\end{array}$ & $\begin{array}{l}\text { May ncrease labor } \\
\text { cost, maintenance } \\
\text { cost, and purchase } \\
\text { fee of trucks. }\end{array}$ & 2 & 5 & 2 & $\begin{array}{l}\text { Daily } \\
\text { inspection }\end{array}$ & 20 & Low & $\begin{array}{l}\text { Based on the } \\
\text { order flow, adjust } \\
\text { amount of trucks. }\end{array}$ \\
\hline & & Less than needed & $\begin{array}{l}\text { Insufficient } \\
\text { understanding of } \\
\text { order flow }\end{array}$ & \begin{tabular}{|l|} 
A: May delay the \\
orders. \\
B: May increase \\
unnecessary truck \\
utilization \\
C: May cause extra \\
purchase of trucks
\end{tabular} & 3 & 7 & 2 & $\begin{array}{l}\text { Daily } \\
\text { inspection }\end{array}$ & 42 & $\begin{array}{l}\text { Relatively } \\
\text { High }\end{array}$ & $\begin{array}{l}\text { Based on the } \\
\text { order flow, adjust } \\
\text { amount of trucks. }\end{array}$ \\
\hline & $\begin{array}{c}\text { Maintenance } \\
\text { of Loading } \\
\text { Trucks }\end{array}$ & $\begin{array}{l}\text { Damages during } \\
\text { the delivery }\end{array}$ & $\begin{array}{l}\text { Fail to maintain } \\
\text { regularly }\end{array}$ & \begin{tabular}{|l|} 
A: May cause \\
safety problem \\
during the \\
delivery \\
B: May cause \\
longer delivery \\
time, hence may \\
delay the orders C: \\
May shorten the \\
trucks' lifetime \\
\end{tabular} & 3 & 7 & 3 & $\begin{array}{c}\text { Regular } \\
\text { maintenance }\end{array}$ & 63 & High & $\begin{array}{l}\text { Follow the regular } \\
\text { maintenance. } \\
\text { Also, implement } \\
\text { monitering } \\
\text { solution. }\end{array}$ \\
\hline
\end{tabular}

\begin{tabular}{|c|c|c|c|c|c|c|c|c|c|c|c|}
\hline Category & Sub-category & Possible Failure & Cause of the failure & Effects of the failure & Occurance & Severerity & Detection & $\begin{array}{l}\text { Current } \\
\text { Control }\end{array}$ & RPN & Action Priorty & Suggested Action \\
\hline \multirow{4}{*}{ Spaces } & \multirow[t]{2}{*}{$\begin{array}{c}\text { Main Storage } \\
\text { Area }\end{array}$} & More than needed & $\begin{array}{l}\text { Insufficient } \\
\text { understanding of } \\
\text { the order flow, } \\
\text { and need for } \\
\text { inventory. }\end{array}$ & $\begin{array}{l}\text { A: May cause } \\
\text { unnecessary waste } \\
\text { of } \\
\text { space } \\
\text { B: May cause } \\
\text { unnecessary } \\
\text { management } \\
\text { cost C: May } \\
\text { cause } \\
\text { overinventory }\end{array}$ & 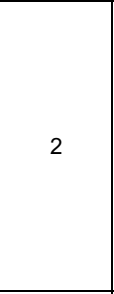 & 6 & 2 & $\begin{array}{c}\text { Visual } \\
\text { inspection }\end{array}$ & 24 & Low & $\begin{array}{l}\text { Analyze the order } \\
\text { flow and adjust the } \\
\text { space based on it. }\end{array}$ \\
\hline & & Less than needed & $\begin{array}{l}\text { Insufficient } \\
\text { understanding of } \\
\text { the order flow, } \\
\text { and need for } \\
\text { inventory. }\end{array}$ & \begin{tabular}{|l|} 
A: May cause low \\
inventory, hence \\
may delay the \\
orders. B: May \\
cause extra \\
delivery fee (from \\
manufacturer)
\end{tabular} & 3 & 7 & 3 & $\begin{array}{c}\text { Visual } \\
\text { inspection }\end{array}$ & 63 & High & $\begin{array}{l}\text { Analyze the order } \\
\text { flow and adjust the } \\
\text { space based on it. }\end{array}$ \\
\hline & \multirow[t]{2}{*}{$\begin{array}{l}\text { Standby } \\
\text { Storage }\end{array}$} & More than needed & \begin{tabular}{|l|} 
A: Insufficient \\
understanding of \\
the order flow \\
B: Insufficient space \\
for \\
Main Storage
\end{tabular} & $\begin{array}{|ll|}\text { A: May cause } \\
\text { unnecessary } & \text { waste } \\
\text { of } & \\
\text { space } & \\
\text { B: May } \\
\text { increase } \\
\text { unnecessary } \\
\text { management } \\
\text { cost } \\
\end{array}$ & 2 & 5 & 2 & $\begin{array}{c}\text { Visual } \\
\text { inspection }\end{array}$ & 20 & Low & $\begin{array}{l}\text { Analyze the order } \\
\text { flow, and current } \\
\text { main storage. Then } \\
\text { adjust the space } \\
\text { based on it. }\end{array}$ \\
\hline & & Less than needed & \begin{tabular}{|l|} 
A: Insufficient \\
understanding of \\
the order flow \\
B: More space for \\
Main Storage than \\
needed.
\end{tabular} & $\begin{array}{l}\text { A: May cause } \\
\text { longer loading } \\
\text { time, hence may } \\
\text { delay the orders. }\end{array}$ & 4 & 6 & 2 & $\begin{array}{c}\text { Visual } \\
\text { inspection }\end{array}$ & 48 & $\begin{array}{l}\text { Relatively } \\
\text { High }\end{array}$ & $\begin{array}{l}\text { Analyze the order } \\
\text { flow, and current } \\
\text { main storage. Then } \\
\text { adjust the space } \\
\text { based on it. }\end{array}$ \\
\hline
\end{tabular}




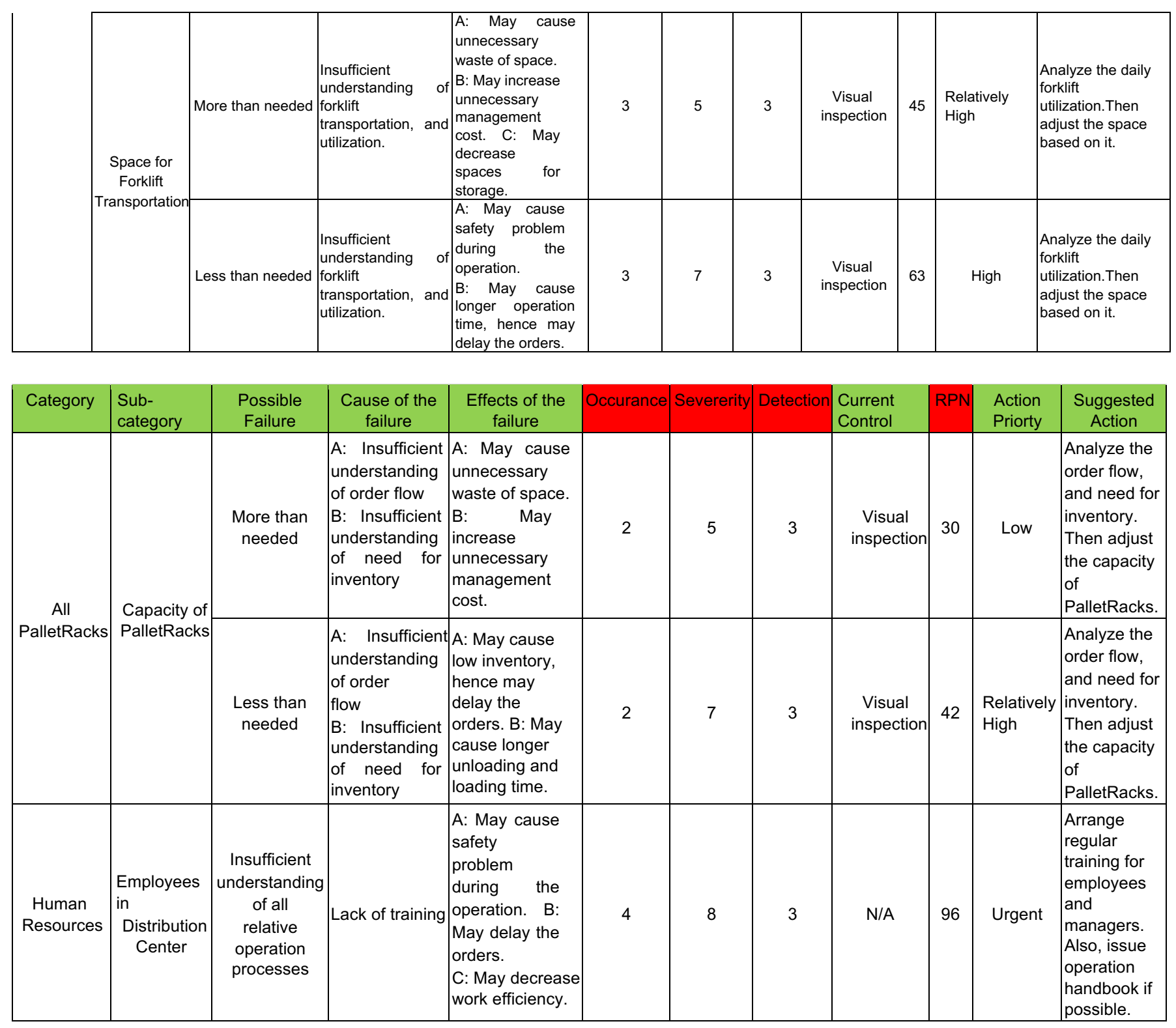

